San Jose State University

SJSU ScholarWorks

Master's Theses

Master's Theses and Graduate Research

Fall 2014

\title{
An Assessment of Artificial Burrows for Burrowing Owls in Northern California
}

Sandra Menzel

San Jose State University

Follow this and additional works at: https://scholarworks.sjsu.edu/etd_theses

\section{Recommended Citation}

Menzel, Sandra, "An Assessment of Artificial Burrows for Burrowing Owls in Northern California" (2014). Master's Theses. 4505.

DOI: https://doi.org/10.31979/etd.fbs7-ck5m

https://scholarworks.sjsu.edu/etd_theses/4505

This Thesis is brought to you for free and open access by the Master's Theses and Graduate Research at SJSU ScholarWorks. It has been accepted for inclusion in Master's Theses by an authorized administrator of SJSU ScholarWorks. For more information, please contact scholarworks@sjsu.edu. 


\title{
AN ASSESSMENT OF ARTIFICIAL BURROWS FOR BURROWING OWLS IN NORTHERN CALIFORNIA
}

\author{
A Thesis \\ Presented to \\ The Faculty of the Department of Environmental Studies \\ San José State University \\ In Partial Fulfillment \\ of the Requirements for the Degree \\ Master of Science
}

by

Sandra Menzel

December 2014 
(C) 2014

Sandra Menzel

ALL RIGHTS RESERVED 
The Designated Thesis Committee Approves the Thesis Titled

\section{AN ASSESSMENT OF ARTIFICIAL BURROWS FOR BURROWING OWLS IN NORTHERN CALIFORNIA}

by

Sandra Menzel

\section{APPROVED FOR THE DEPARTMENT OF ENVIRONMENTAL STUDIES \\ SAN JOSÉ STATE UNIVERSITY}

December 2014

Dr. Lynne Trulio Department of Environmental Studies

Dr. Scott Shaffer Department of Biological Sciences

Jack Barclay M. S. Senior Wildlife Biologist at Albion Environmental, Inc. 


\section{ABSTRACT \\ AN ASSESSMENT OF ARTIFICIAL BURROWS FOR BURROWING OWLS IN NORTHERN CALIFORNIA \\ by Sandra Menzel}

This study assesses artificial burrows as a management tool for burrowing owls (Athene cunicularia) at two study sites in northern California. The results of t-tests showed that artificial burrows that received annual surface maintenance $(n=113)$ at one site were occupied for a significantly $(p \leq 0.003)$ greater number of years than non-maintained $(n=51)$ artificial burrows at the other site. Maintained burrows were occupied for a mean of 1.90 years ( $S D=2.04)$, compared to a mean of 0.45 years $(\mathrm{SD}=0.97)$ for non-maintained burrows. Even with maintenance, occupancy rates dropped from 31\% during the first year to $8 \%$ during the third year post-installation. Maintenance or reinstallation of the entire burrow system appears to be crucial for longer-term use. The results of chi-squared goodness-of-fit tests showed no significant difference in nesting success ( $\geq 1$ fledgling/pair) between natural and artificial burrows at either of the study sites $\left(\chi^{2}=2.75\right.$ and $6.76, \mathrm{df}=3, \mathrm{p}>0.05)$. Of 120 burrowing owls raised in maintained artificial burrows, 70\% were re-sighted occupying artificial burrows during subsequent breeding seasons, compared to $30 \%$ occupying natural burrows. Only $3 \%$ of these owls occupied their natal burrow during the first nesting season post-fledging. Of those owls that were re-sighted during two or more nesting seasons, almost half (48\%) occupied different artificial burrows from one year to the next. 


\section{ACKNOWLEDGEMENTS}

I thank my thesis advisor Dr. Lynne Trulio, and my committee members Dr. Scott Shaffer and Jack Barclay for their thoughtful reviews, comments, and edits on my thesis drafts. I am especially grateful to Jack for being an attentive mentor and teacher, and for generously sharing his vast knowledge and experience, as well as the data for this thesis.

A brief accolade: Jack Barclay has worked on raptor conservation and research for over 35 years, including 24 years of research on burrowing owls in California. Amongst his many accomplishments is the successful management of a burrowing owl population at San José International Airport from 1989 through 2012. His proactive management approach has demonstrated how burrowing owls can be accommodated at airports without compromising aviation safety.

Jack has been a member of the California Burrowing Owl Consortium since 1990 and he was chairperson of the Burrowing Owl Mitigation Committee. This committee prepared the Burrowing Owl Survey Protocol and Mitigation Guidelines, which became the basis for the Department of Fish and Game's Staff Report on Burrowing Owl Mitigation in 1995.

He organized and chaired the first California Burrowing Owl Symposium in Sacramento in 2003 and was senior editor for the Proceedings of the California Burrowing Owl Symposium, published in 2007. Jack has contributed numerous journal articles on burrowing owls to the scientific literature, including: Burrowing 
Owl Management at Mineta San José International Airport (2003), A simple artificial burrow design for Burrowing Owls (2008a), A technique for nighttime trapping of Burrowing Owls with a bow net (2008b), and Long-term population dynamics of a managed burrowing owl colony (2011). Thank you, Jack, for nudging me toward graduate school, and more importantly for your diligence and vital contributions to burrowing owl conservation and research.

Furthermore, I thank staff at Albion Environmental, Inc. who helped collect data at the two study sites over the years, especially Jeff Diehl and Lindsay Harman. I also thank staff at San José International Airport (especially Jerry Gutierrez and Vivian Robles) and Sharpe Depot for their support with site access, as well as artificial burrow installation and maintenance.

Many thanks to my wonderful graduate cohort, friends, and family for their continued support, encouragement, and advice. Ted Fairbanks, thank you for all your superb TLC you so generously provided during my graduate studies.

\section{DEDICATION}

I dedicate this research to my fabulous parents, Eberhard and Ursula Menzel. Ich danke Euch dafür, dass Ihr Anja und mir die Begeisterung für die Natur und die Zuneigung zu allen Lebewesen schon früh mit auf den Weg gegeben habt.

Ella - keep it up! 


\section{TABLE OF CONTENTS}

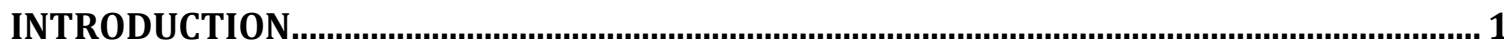

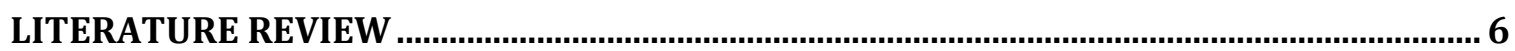

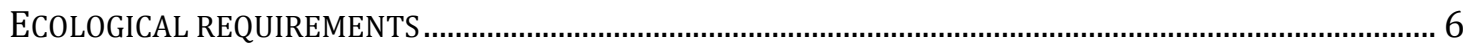



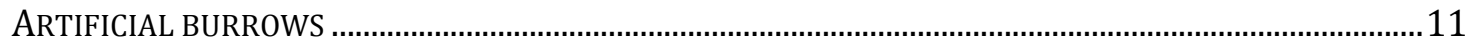

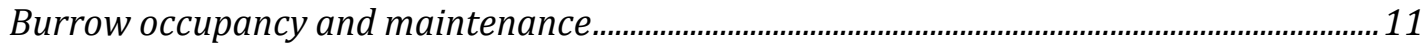

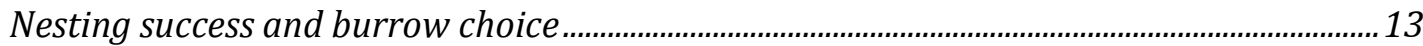

NEST-SITE FIDELITY AND NATAL PHILOPATRY ……..........................................................................

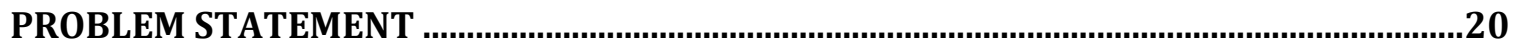

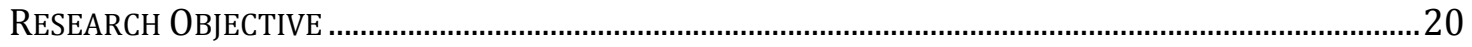

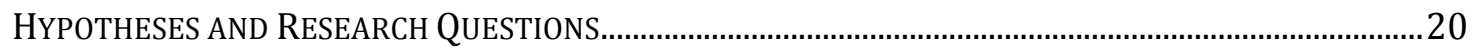

METHODS

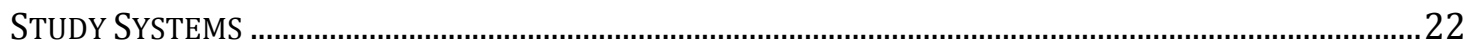

Norman Y. Mineta San José International Airport ....................................................................22

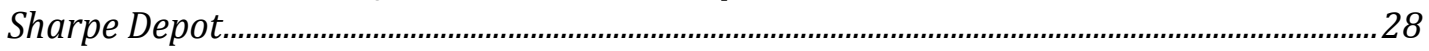

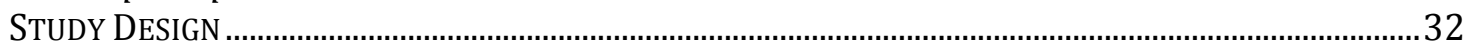

Norman Y. Mineta San José International Airport …...............................................................

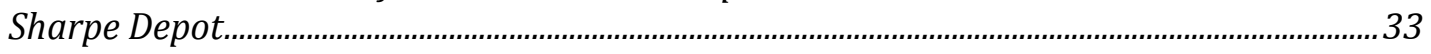

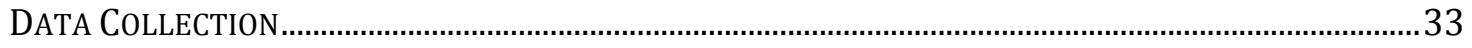

Norman Y. Mineta San José International Airport ..................................................................

Sharpe Depot



RESULTS

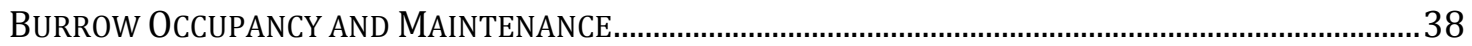

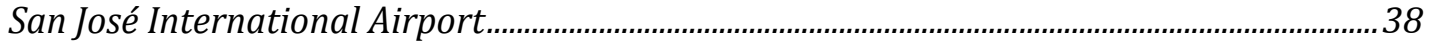

Sharpe Depot

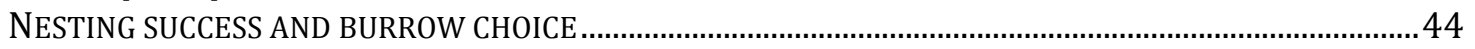

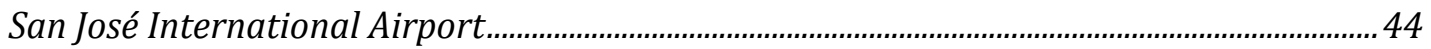

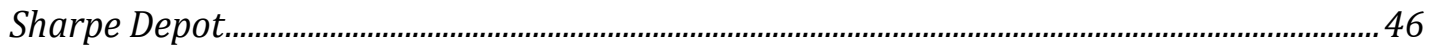



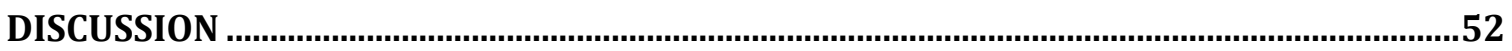

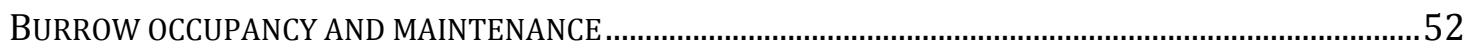

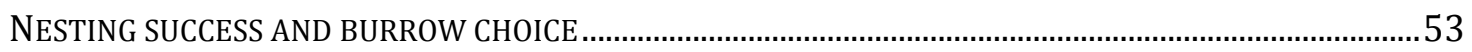



MANAGEMENT AND CONSERVATION IMPLICATIONS ............................................................57

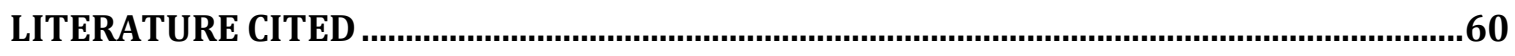

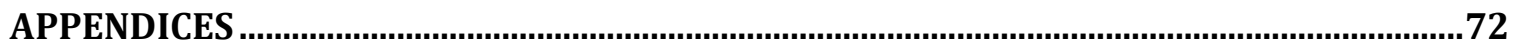




\section{LIST OF FIGURES}

Figure 1. Study locations San José International Airport and Sharpe Depot, California............ 5 Figure 2. San José International Airport configuration and artificial burrow locations for

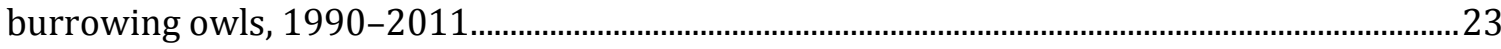

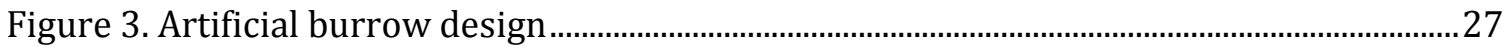

Figure 4. Sharpe Depot configuration and artificial burrow locations for burrowing owls, 1999-2012

Figure 5. Number of artificial burrows in the ground each year, compared to artificial burrows with entrance and tunnel actually open, and artificial and natural burrows occupied by nesting burrowing owls at San José International Airport, 1990-2011.

Figure 6. Number of artificial burrows in the ground each year, compared to artificial burrows with entrance and tunnel actually open, and artificial burrows and natural burrows occupied by nesting burrowing owls at Sharpe Depot, 1997-2012.. 40

Figure 7. Comparison of the proportions of artificial burrows occupied by nesting burrowing over time at San José International Airport and Sharpe Depot, 1991-2012 .........41 Figure 8. Locations of artificial burrows for burrowing owls at San José International Airport, 1990-2011.

Figure 9. Locations of artificial burrows for burrowing owls at Sharpe Depot, 1999-2012

Figure 10. Natural burrow locations occupied by nesting burrowing owls raised in artificial burrows at San José International Airport, 1990-2011. 45

Figure 11. Burrowing owls raised in artificial burrows at San José International Airport, returning for nesting in artificial or natural burrows, 1990-2011

Figure 12. Natal and breeding dispersal by burrowing owls raised in artificial burrows at San José International Airport, 1990-2011

Figure 13. Natal and breeding dispersal by burrowing owls raised in artificial burrows at San José International Airport, 1990-2011. 


\section{LIST OF TABLES}

Table 1. Common and scientific name of 28 bird species observed at San José International Airport during the Wildlife Hazard Assessment from 1 July 2009 to 30 June 2010................24 Table 2. Common and scientific name of 12 mammal species incidentally observed at San José International Airport.

Table 3. Nesting success ( $\geq 1$ fledgling/pair) of burrowing owls in natural and artificial burrows at San José International Airport, 1990-2011.

Table 4. Nesting success ( $\geq 1$ fledgling/pair) of burrowing owls in natural and artificial burrows at Sharpe Depot, during those years that artificial burrows were occupied, 19992001 and 2003-2005.

Table 5. Compass directions of natal and breeding dispersal movements of 117 burrowing owls raised in artificial burrows at San José International Airport, 1990-2011. 


\section{LIST OF APPENDICES}

Appendix 1: Burrowing owl monitoring map for San José International Airport..................82

Appendix 2: Burrowing owl data collection sheet for San José International Airport............83

Appendix 3: Burrowing owl survey map for Sharpe Depot Depot........................................84

Appendix 4: Institutional Animal Care and Use Committee Approval......................................85 


\section{INTRODUCTION}

The western burrowing owl (Athene cunicularia hypugaea) inhabits open grasslands and deserts, and occurs west of the Great Lakes, into southern Canada, and northern Mexico (Klute et al. 2003). Burrowing owls typically nest in areas of short or sparse vegetation and an important habitat requirement is the availability of burrows (Plumpton and Lutz 1993, Poulin et al. 2005). This is the only owl that roosts and nests in underground burrows. Burrows are typically dug by other animals, especially colonial mammals, such as ground squirrels (Spermophilus beecheyi) or prairie dogs (Cynomys spp.) (Thomsen 1971, Zarn 1974). Burrowing owls show a high degree of site tenacity, particularly during the nesting season, and they often reoccupy nest burrows in subsequent years (Martin 1973, Green 1983, Rich 1984).

Burrowing owl populations have drastically declined in many parts of their North American range over the last 30 years (Haug et al. 1993, James and Espie 1997, Klute et al. 2003). Once common in grasslands, this species is listed as federally endangered in Canada since 1995 (Wellicome and Haug 1995), threatened in Mexico since 1994 (Sheffield 1997), and has special status as endangered, threatened, or a species of special concern in 11 states in the United States (James and Espie 1997, Klute et al. 2003). 
The conversion of grasslands to urban areas or agriculture, associated ground-disturbing activities (e. g., disking, trenching, and bulldozing), and the eradication of burrowing mammals are among the factors contributing to the population decline (Haug et al. 1993). Habitat conversion reduces natural burrow availability, foraging area, and prey abundance. As a consequence, owls are displaced from previously occupied areas, and their breeding opportunities may be reduced (Haug et al. 1993).

Ground disturbing activities can also kill burrowing owls seeking refuge from the disturbance in underground burrows; however, it is unlawful to "take" (defined in Section 86 of the Fish and Game Code as "hunt, pursue, catch, capture, or kill, or attempt to hunt, pursue, catch, capture, or kill") individual owls or destroy their nests and eggs. Burrowing owls and their nests are protected by the Migratory Bird Treaty Act of 1918 (16 U.S.C. §§703-711) and by California Fish and Game Code $\S 3503$ - Unlawful destruction of nests or eggs; §3503.5 - Birds-of-prey or their eggs; and $\S 3800$ - Nongame birds. In California, where the burrowing owl was listed as a Species of Special Concern in 1978 (Remsen 1978), significant impacts to birds or their habitat must be mitigated for under the California Environmental Quality Act (CEQA).

One common strategy to avoid take of burrowing owls and to mitigate for the loss of natural burrows, has been the installation of artificial burrows outside the ground-disturbance area (Trulio 1995, Smith and Belthoff 2001a). One artificial burrow design, described by Barclay (2008a), consists of three components: a nest 
chamber made from an irrigation valve box; a tunnel made from flexible, perforated plastic drain pipe; and a hollow concrete block used as an entrance, anchoring the drain pipe at the soil surface.

After the installation of artificial burrows, owls are passively or actively relocated out of the disturbance area in hope that they occupy these substitute burrows (Trulio 1995, 1997). Passive relocation, combined with the installation of artificial burrows, has been used as a short-term mitigation tool in the San Francisco Bay Area and elsewhere since the 1990s. These methods enable ground disturbing activities to move forward without directly harming burrowing owls that occupy natural burrows within areas of ground disturbance. Yet, the outcome of most relocation efforts remained unknown or resulted in fewer breeding pairs at the mitigation site than at the original site (Trulio 1995, Trulio 1997, Smith and Belthoff 2001a).

A number of studies have compared productivity of owls nesting in artificial and natural burrows (e. g., Botelho and Arrowood 1998, Smith and Belthoff 2001b, Smith et al. 2005, Barclay et al. 2011), but only one study has examined the longevity of artificial burrows (Belthoff and Smith 2003). Belthoff and Smith (2003) researched how long artificial burrows remained available and at what rate burrowing owls occupied them during a 5-year study in southwestern Idaho. However, no studies have examined the long-term effects of artificial burrows on the nest site selection of owls and whether burrowing owls raised in artificial burrows choose to nest in artificial burrows significantly more often than they do in 
natural burrows. Also lacking are studies assessing nest-site fidelity (an individual occurring at the same location during successive nesting seasons) and natal philopatry (the tendency of an individual to stay in or return to its natal area) of burrowing owls raised in artificial burrows (Newton 2008).

Here, I analyzed data collected at two study sites in northern California where artificial burrows were installed as mitigation for the loss of occupied natural burrows. Data were collected during a 22-year period (1990-2011) at Norman Y. Mineta San José International Airport (SJC) and during a 16-year period (19972012) at the Defense Logistics Agency's Distribution Depot San Joaquin - Sharpe Site (Sharpe Depot) (Figure 1). I participated in data collection from 2009 through 2012.

I evaluated artificial burrow occupancy rates (percent of artificial burrows occupied, relative to the total number of artificial burrows), the effects of burrow maintenance on occupancy rates, as well as the effects of burrow type (artificial vs. natural) on nesting success ( $\geq 1$ fledged young). I also examined burrow type choice, nest-site fidelity, and natal philopatry of burrowing owls raised in artificial burrows. This study provides information on the effectiveness of artificial burrows as a mitigation tool, and presents recommendations for artificial burrow maintenance and proximate habitat requirements that may enhance burrowing owl management over the long-term. 


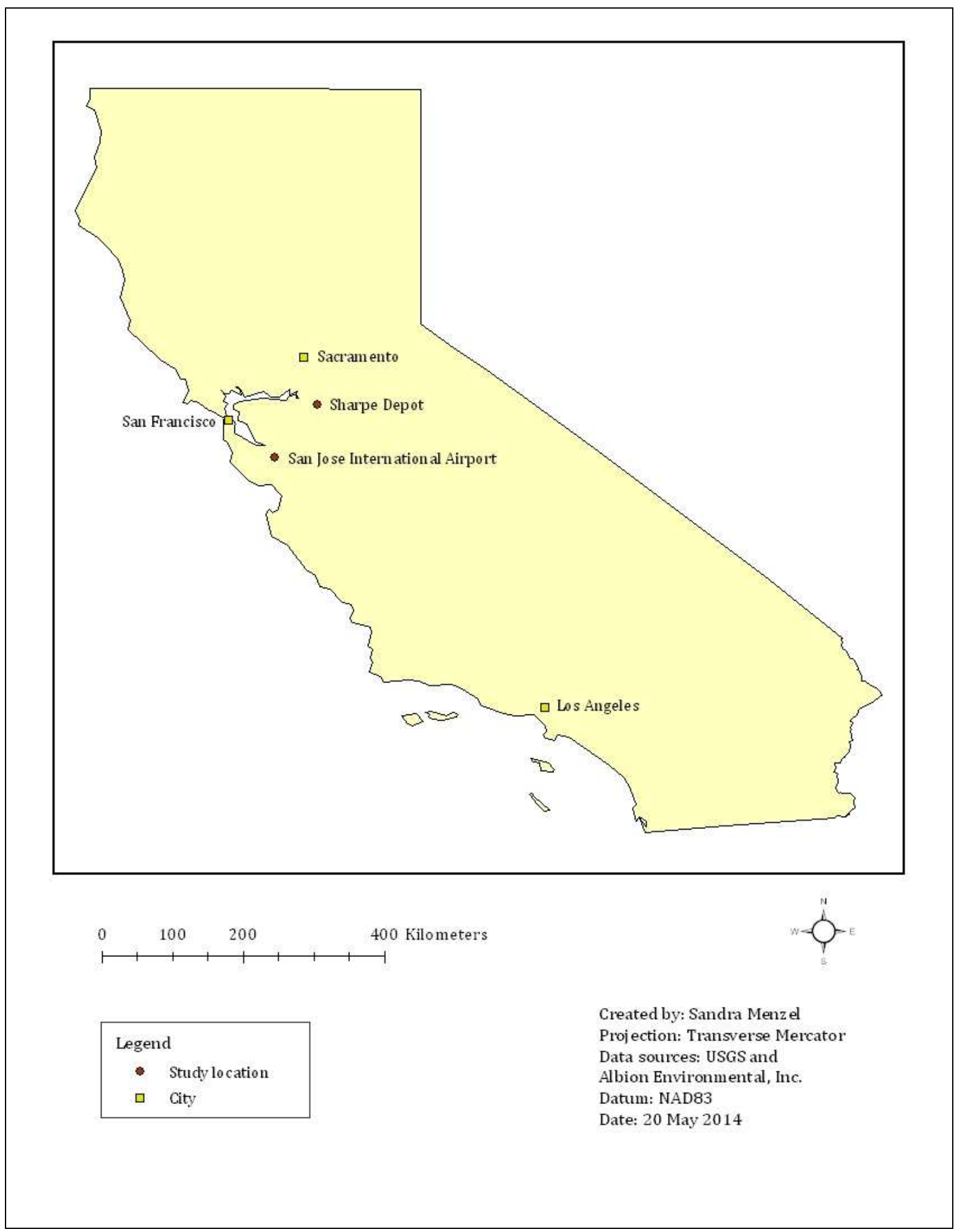

Figure 1. Study locations San José International Airport and Sharpe Depot, California. 


\section{LITERATURE REVIEW}

\section{Ecological Requirements}

Western burrowing owls occur in North America to the eastern limits of the Great Plains and from southern British Columbia to Manitoba and into Central America as far south as Panama (Haug et al. 1993). In the southern portion of their North American range, owls are generally year-round residents, though some move short distances between nesting and wintering grounds (Shuford and Gardali 2008). Owls that nest in the northern part of the range, however, migrate south (Shuford and Gardali 2008). Some of the largest breeding and wintering populations occur in California (James and Ethier 1989, DeSante et al. 2007).

Burrowing owls occur primarily in open, treeless grasslands, deserts, prairies, and agricultural lands. In urban areas, they persist at airports, golf courses, cemeteries, vacant lots, and along road allowances (Haug et al. 1993). The most important habitat characteristics for burrowing owls are a burrow for nesting and roosting, short vegetation around burrows, and adequate foraging habitat. In some areas, owls prefer locations with high burrow densities (Plumpton 1992, Plumpton and Lutz 1993, Desmond and Savidge 1999, Lantz et al. 2007). Owls can dig their own burrows (Thomsen 1971, Barclay et al. 2011) in loose, sandy soils, but they usually use burrows dug by mammals, such as ground squirrels, prairie dogs, badgers (Taxidea taxus), coyotes (Canis latrans), or foxes (Vulpus spp.) (Zarn 1974). 
Burrowing owls' close association with these semi-fossorial mammals suggests that they depend on pre-existing burrows (Haug et al. 1993).

The burrowing owl is described as a semi-colonial species. Neighboring pairs of nesting owls may increase productivity through increased predator detection (Beradelli et al. 2010), but densities of nesting pairs in one colony vary (Haug et al. 1993). In Oklahoma, for example, 16.4 nest burrows were located on one hectare (Butts 1973), compared to 0.18 nest burrows per hectare in Florida (Wesemann and Rowe 1987). The distance between nest burrows varied between $<14 \mathrm{~m}$ in Texas (Ross 1974) and $900 \mathrm{~m}$ in Idaho (Gleason 1978). In the agricultural landscape of the Imperial Valley in California, Rosenberg and Haley (2004) found pairs nesting as close as $7 \mathrm{~m}$ from each other, with an average distance of $147 \mathrm{~m}$.

Thomsen (1971) noted that mostly the males were engaged in defending the pair's territory, but that defensive behavior at the boundary of two territories was seldom observed; thus, territory size was difficult to determine at Oakland Municipal Airport in California. She estimated territory sizes of six pairs ranging between 0.04 ha and 1.6 ha. The territory used by each pair was considerably smaller than the home range (Thomsen 1971).

Home range size varies widely. Researchers have found ranges up to 4.81 $\mathrm{km}^{2}$ (mean $2.41 \mathrm{~km}^{2}$ ) around the nest burrow (Haug and Oliphant 1990, Gervais et al. 2003). Burrowing owls feed opportunistically and their diet includes arthropods, small mammals, amphibians, reptiles, and small birds. They are primarily crepuscular foragers during the non-breeding season (September through February 
in California), and cathemeral during the breeding season (March through August in California) (Green et al. 1993).

Burrowing owls have numerous mammalian, avian, and reptilian predators. Mammal species include badger, domestic cat (Felis catus), opossum (Didelphis virginiana), and skunk (Mephitis spp.) (Green 1983, Haug 1985, Millsap and Bear 1988). Burrowing owl remains have been found in various raptor species' nests, such as red-tailed hawk (Buteo jamaicensis), Cooper's hawk (Accipiter cooperii), peregrine falcon (Falco peregrinus), and great horned owl (Bubo virginianus). American crow (Corvus brachrhynchos) and common raven (Corvus corax) also prey on burrowing owls, especially the young (Millsap and Bear 1988). Snakes, such as rattlesnakes (Crotalus spp.), eat eggs and nestlings.

\section{Natural Nest Burrows}

As guidance for determining future artificial burrow design and placement, Belthoff and King (2002) assessed burrowing owls' preferences of natural nest burrow characteristics. They measured physical, vegetative, and topographic characteristics of nest locations, and compared burrow attributes between used and unused nest burrows to determine which features were important in nest site selection. They found that tunnel angle was the only exterior burrow feature that was significantly different between used and unused burrows. Owls preferred tunnels that were less steep. Specific above-ground features appeared not to be the main factor driving burrow choice, and underground nest burrow features, such as 
nest chamber and tunnel dimensions, might be more important to burrowing owls when selecting a nest site (Smith and Belthoff 2001b).

Butts and Lewis (1982) excavated 13 natural nest burrows and measured their underground attributes. They found that the tunnel diameter remained mostly uniform (14-15 cm wide and 11-13 cm high) from the entrance to the nest chamber and was $107-213 \mathrm{~cm}$ long. Nest chambers were $38-107 \mathrm{~cm}$ below the ground, "roughly circular or oblong," about as high as the tunnel, but almost twice as wide (Butts and Lewis 1982).

Poulin et al. (2005) examined nest burrow selection by burrowing owls on a landscape level and also by comparing burrow attributes (entrance direction, entrance height, mound height, mound area, and burrow density within $75 \mathrm{~m}$ ) between used and unused natural nest burrows. The study area consisted of nonirrigated cereal crop fields (90\%), interspersed with few small patches of native grassland (7\%). During one breeding season, Poulin et al. (2005) mapped and measured every burrow within a $75 \mathrm{~m}$ radius of a nest burrow. Of the 584 burrowing owl pairs that were observed during the 12-year study period, $3 \%$ nested in crop fields and 84\% in grassland pastures, even though crop fields dominated the landscape. Compared with other suitable nest burrows, burrowing owls selected burrows in areas with high burrow density within $75 \mathrm{~m}$. This preference for nesting in grasslands and areas with high burrow densities, confirms results of other studies (e. g., Martin 1973, Haug et al. 1993, Plumpton and Lutz 
1993, Desmond and Savidge 1999, Crowe and Longshore 2013, Ronan and Rosenberg 2014).

Ronan and Rosenberg (2014) experimentally investigated the importance of additional burrows around nest burrows, so called satellite burrows. They blocked access to all satellite burrows within $20 \mathrm{~m}$ of 11 nest burrows and analyzed the owls' responses. They found that adult owls and their young at five of the seven successful nest burrows moved away from treated areas and did not return, whereas owls at 11 control nest burrows did not move. All family groups that moved from treated locations, relocated to areas with high burrow density. The results of this study furthermore support that burrowing owls prefer areas in which numerous satellite burrows are available (Ronan and Rosenberg 2014).

Holmes et al. (2003) examined differences in burrowing owl nesting success, burrow longevity, and burrow reuse in three different soil types in Oregon. Of 99 nesting attempts during the three-year study period, nests were most successful in sandy loam (71\%), compared to silt loam (58\%), and loamy sand (43\%). The nesting success rates corresponded with longevity of burrows compared across soil types; burrows were available for owls the longest in sandy loam and collapsed most frequently in loamy sand. Interestingly, reuse of burrows by burrowing owls was greatest in sandy loam (94\%), compared to loamy sand (87\%) and silt loam (50\%). Holmes et al. (2003) were not able to determine if the same owls reused the same burrows during consecutive nesting seasons because individuals were not banded during this study. They did determine however that burrows, in which 
young were successfully raised, were more likely to be occupied during the next nesting season.

\section{Artificial Burrows}

Collins and Landry (1977) pioneered the installation of artificial burrows as a maintenance and enhancement technique for burrowing owl habitat in southern California. They first installed artificial burrows to replace natural burrows that had collapsed during disking operations. They then installed artificial burrows in adjacent areas that had no natural burrows and found that suitable burrows directly attracted burrowing owls to these areas. Of their 30 artificial burrows, 20 (67\%) were occupied almost immediately after installation. Most of the artificial burrows silted during winter rains and needed renovation each spring.

Since this first study by Collins and Landry (1977), artificial burrows have been used for numerous applications, such as studying nesting biology (e. g., Henry and Blus 1981), enabling reintroduction projects (Poulin et al. 2006), mitigating temporary ground disturbance or permanent habitat loss from construction projects (e. g., Smith and Belthoff 2001a, Barclay et al. 2011), and enhancing nesting or over-wintering habitat (e. g., Houston et al. 1996, Keppers et al. 2008). Johnson et al. (2013) provided a comprehensive review of different artificial burrow designs.

\section{Burrow occupancy and maintenance}

Research by Belthoff and Smith (2003) in Idaho aimed to determine annual occupancy rates of artificial burrows by burrowing owls and examine patterns of 
reuse over a 5-year period. They installed 104 clusters with two or three artificial burrows at each cluster. The clusters encircled previously used natural burrows. They closed entrances to natural burrows within $10 \mathrm{~m}$ of each cluster. They then surveyed the artificial burrows during five consecutive breeding seasons for occupancy, which they determined by the presence of a pair of owls at the burrow or eggs in the nest chamber. Belthoff and Smith (2003) stated that artificial burrows were routinely maintained and cleaned of debris, though they did not provide a specific maintenance protocol or schedule. They found that burrowing owls nested at artificial burrow clusters at an average annual occupancy rate of 55\% throughout the 5-year study period. They also found that owls used over two-thirds of the clusters for nesting during at least two years and almost one-third of clusters during four or more years.

Belthoff and Smith's (2003) study showed that with periodic maintenance, artificial burrows remained suitable for use by burrowing owls over a 5-year period; however, they did not include a control group of artificial burrows that were not maintained to compare the effect of maintenance versus non-maintenance on occupancy rates. They also did not specifically observe if the same individual owls reoccupied burrows in consecutive years or if different individuals occupied them each year.

One study suggested that leaving some of the old nesting material from previous nesting seasons inside the nest chambers during annual maintenance may increase the likelihood of re-occupancy of artificial burrows the following nesting 
season (Riding 2010). Riding (2010) found that removing all old nesting material resulted in a significant decrease in burrow reuse by migratory burrowing owls in Idaho.

\section{Nesting success and burrow choice}

During another study on artificial burrows, Smith and Belthoff (2001b) explored the effects of three different chamber sizes and two different tunnel diameters on burrowing owls' nesting success and burrow choice. The study's objectives were to determine if different artificial burrow chamber sizes and tunnel diameters had an effect on the owls' reproductive rates and burrow use. Smith and Belthoff (2001b) installed 46 artificial burrow clusters with three different chamber sizes at each cluster. The small chamber had a $30 \mathrm{~cm}$ diameter and was $35 \mathrm{~cm}$ high. The length, width, and height of the medium and large chambers were $30 \times 30 \times 20$ $\mathrm{cm}$ and $50 \times 35 \times 40 \mathrm{~cm}$, respectively. The tunnel diameter was the same for these artificial burrows $(15 \mathrm{~cm})$. As in the earlier study design, the clusters encircled previously used natural burrows, and entrances to natural burrows within $10 \mathrm{~m}$ of all clusters were closed. They also installed 48 clusters with two different tunnel diameters $(10 \mathrm{~cm}$ or $15 \mathrm{~cm})$. The chamber size was the same for this group of artificial burrows; $30 \mathrm{~cm}$ in diameter and $35 \mathrm{~cm}$ high. They monitored all burrows for two consecutive breeding seasons and recorded reproductive and occupancy rates. They found that neither chamber size nor tunnel diameter had an effect on the number of eggs or fledglings, but that owls selected the large chamber 
significantly more often than the medium or small chamber, and selected the smaller tunnel diameter significantly more often than the larger diameter tunnel.

One limitation for this experiment was that the results might not be applicable at other geographic locations with different fossorial mammals providing different sized burrows. For example, in areas where badgers provide relatively large burrows, owls may prefer larger nest chambers whereas in areas where ground squirrels provide relatively small burrows, owls may prefer smaller nest chambers (Martin 1973, Butts and Lewis 1982, Haug 1985, MacCracken et al. 1985). Similarly, the preference for smaller or larger diameter tunnels may depend on which predator species are present in different areas and preference may thus vary geographically (Green 1983, Haug et al. 1993, Green and Anthony 1997).

Smith and Belthoff (2001b) reported that the mean number of fledglings in artificial burrows $(5.3 \pm 0.4 ; \mathrm{n}=32)$ was slightly higher than the mean number of fledglings in natural burrows $(4.2 \pm 0.6$; $\mathrm{n}=13$ ); however, these results are not statistically comparable because the number of fledglings in artificial burrows was a count, whereas the number of fledglings in natural burrows was an estimate based on observations. Barclay et al. (2011) also found that pairs in artificial burrows produced a higher average number of fledglings $(\overline{\mathrm{x}}=3.80 ; \mathrm{SD}=1.23)$ compared to the estimated average number produced in natural burrows $(\bar{x}=3.03$; $S D=0.89)$, whereas Smith et al. (2005) found no significant difference in fecundity between burrow types. Barclay et al. (2011) also reported that the average nesting success 
( $\geq 1$ fledgling/pair) in artificial burrows was $11 \%$ higher than in natural burrows, which was a marginally significant difference.

Brown and Collopy (2013) examined whether providing nest boxes for birds could lead to nest type imprinting, limiting young that were reared in artificial nest boxes from emigrating to areas without these artificial structures. They studied American kestrels (Falco sparverius) reared in an area with a network of nest boxes in Florida and found that many juvenile kestrels that fledged from nest boxes emigrated to nest in areas without nest boxes. Similarly, adult individuals

previously unfamiliar with nest boxes chose to nest in artificial nest boxes instead of natural cavities. Adult burrowing owls do not appear to be restricted to one specific type of burrow and can choose between natural and artificial nest burrows, though no previous study has specifically explored nest burrow choice by burrowing owls raised in artificial burrows.

\section{Nest-Site Fidelity and Natal Philopatry}

The tendency of an adult individual to return each season to the same nest site is known as nest-site fidelity, whereas natal philopatry is defined as the tendency of an individual to stay in or return to its natal area (Newton 2008). Most animal species show some degree of nest-site fidelity and natal philopatry. In most bird species, males either remain in their natal territory until the next breeding season or occupy an adjacent area; females, on the other hand, tend to disperse (Greenwood and Harvey 1982). When given the choice, offspring almost always 
choose to stay or return to their natal areas because dispersal is more costly than natal philopatry.

The main reasons for nest-site fidelity and natal philopatry in individuals of many species are avoidance of energy expenditure from movement and familiarity with the area, including both its resources and hazards (Sanz-Aguilar 2012). The benefits of being familiar with an area and the local conditions may include increased foraging efficiency (having prior knowledge of the food sources), reproductive performance (knowledge of high quality breeding sites and perhaps presence of high quality mates), and survival (knowledge of predator locations and habits) (Sanz-Aguilar 2012). In addition to the energetic cost of movement, moving away from a familiar area also increases the risk of predation during travel and potentially ending up in an area less optimal for foraging and breeding (Pärt 1995).

Liberg and von Schantz (1985) noted that natal philopatry might be sexbiased, depending on the mating system of the species. In their conceptual model, natal philopatry in monogamous birds would be male-biased and dispersal femalebiased. The reason for this is that a monogamous mature female may cheat on her mother by laying her eggs into her parents' nest and she will thus not be tolerated in her natal area during the next breeding season. Mature monogamous males have no such potential for cheating and are allowed to stay. In polygynous or promiscuous birds, individuals of both sexes can cheat on their parents and thus neither sex is allowed to stay (Liberg and von Schantz 1985). 
Burrowing owls are described as predominantly monogamous and occasionally polygynous (Haug 1993, Barclay and Menzel 2011), and some offspring may result from extra-pair fertilization (Johnson 1997). From year to year, though, pair bonds are not necessarily permanent with different rates of pair fidelity at different locations (Thomson 1971, Martin 1973, Millsap and Bear 1990).

Observations of nest-site fidelity and natal philopatry in burrowing owls also varied at different locations. In New Mexico, Martin (1973) observed that of nine banded birds of each sex, six males and two females returned to their former breeding area. None of the pairs in which both male and female were banded were paired during the subsequent year. In Florida, where birds exhibited strong pair fidelity ( $92 \%$ of pairs remained together), males reused former nest territories more frequently than females (Millsap and Bear 1997). Lutz and Plumpton (1999) reported that of the 555 owls that they banded in a migratory population in Colorado, only a small fraction (8\%) returned to the area. Reasons for the low return rate were mortality and emigration. Lutz and Plumpton (1999) suggested that migration might reduce the benefits of returning to a familiar nest site. Of those owls that returned, $19 \%$ were male and $14 \%$ female. Seventy-five percent of the males nested in formerly used sites, compared to $63 \%$ of the females.

In a non-migratory population in the Imperial Valley in California, 92\% of 67 pairs of owls in which both mates were alive during the subsequent breeding season remained paired (Catlin et al. 2005). During their 5-year study, Catlin et al. (2005) found that 37 of 101 (37\%) female owls and 49 of 152 (32\%) male owls dispersed. 
Of the total 253 owls, 167 (66\%) remained within $100 \mathrm{~m}$ of their previous nest, while 59 (69\%) of those owls that dispersed, remained within $400 \mathrm{~m}$ of their previous nest. Dispersal was closely related to nesting success; owls whose nest failed were more likely to disperse and to disperse longer distances than owls that nested successfully. Of the females with failed nests, $73 \%$ dispersed, compared to $30 \%$ of females with successful nests. Successful females dispersed a mean distance of $357 \mathrm{~m}$, compared to $924 \mathrm{~m}$ for females with failed nests. Similarly, $65 \%$ of males with failed nests dispersed, compared to $25 \%$ of males with successful nests. Successful males dispersed a mean distance of $326 \mathrm{~m}$, compared to $629 \mathrm{~m}$ for males with failed nests.

Wellicome et al. (1997) found that in a migratory population in Saskatchewan, adult female burrowing owls showed less nest-site fidelity than males and dispersed greater distances between nesting seasons. Adults showed more nest-site fidelity than juveniles, though juvenile males were more philopatric than females; more than $50 \%$ of males nested in their natal borrow, compared to $12 \%$ of females. Half of the females that did not nest in their natal burrow chose burrows 1-10 km away.

In a non-migratory population at Oakland Municipal Airport in California, Thomsen (1971) also found that adults showed greater nest-site fidelity than juveniles. Of 21 adults and 30 young banded during the first nesting season of her study, 17 adults (81\%) and nine of the young (30\%) were still present on the airport during the following nesting season. Unfortunately, Thomsen did not include the 
sex of these individuals, nor if they occupied the same or a different burrow during the subsequent year.

During nest burrow selection, Thomsen (1971) observed some owls only at one burrow, while other owls visited a number of different burrows before choosing a nest burrow. Fifty percent of the pairs switched burrows one or more times during one nesting season. Which individual of a pair made the final nest burrow selection remained unclear (Thomson 1971). 


\section{PROBLEM STATEMENT}

\section{Research Objective}

Previous research has shown that burrowing owls readily occupy artificial burrows, including those that are installed to mitigate for the loss of natural burrows. However, only one study has investigated longevity of regularly maintained burrows during a 5-year period, and no study has yet shown how long these burrows might be occupied without maintenance.

My thesis research addresses long-term occupancy rates of maintained and non-maintained artificial burrows, as well as choice of burrow type (natural vs. artificial burrows) by owls raised in artificial burrows. I evaluated nesting success at natural and artificial burrows, and assessed nest-site fidelity and natal philopatry

of burrowing owls raised in artificial burrows. I conducted analyses of long-term data on these aspects of artificial burrows to provide insights for the development of maintenance protocols and proximate habitat requirements for artificial burrows, essential for the long-term persistence of burrowing owls at managed sites.

\section{Hypotheses and Research Questions}

This research addressed the following hypotheses and research questions:

H1. Burrowing owls will occupy maintained artificial burrows (SJC) for a greater number of breeding seasons than unmaintained artificial burrows (Sharpe Depot). 
H2. A higher percentage of pairs of burrowing owls will nest in maintained artificial burrows than in natural burrows.

H3. Nesting success rate does not differ between artificial and natural burrows.

H4. Burrowing owls raised in maintained artificial burrows will nest in artificial burrows more often than in natural burrows.

H5. Burrowing owls nesting in a particular artificial burrow are more likely to nest in the same burrow the following breeding season rather than nesting in a different burrow (nest-site fidelity).

H6. Burrowing owls raised in a particular artificial burrow are more likely to nest in a different burrow rather than nesting in their natal burrow (natal philopatry).

Q1. What percentage of artificial burrows was occupied the first year after installation and each year thereafter?

Q2. What is the range of distances between burrowing owls' natal burrows and their first nest burrows (natal dispersal), and nest burrows during subsequent nesting attempts (breeding dispersal)?

Q3. What are the compass directions of natal dispersal and breeding dispersal movements? 


\section{METHODS}

\section{Study Systems}

\section{San José International Airport}

San José International Airport (SJC) is located in the City of San José, Santa Clara County, California (Figure 1) approximately $80 \mathrm{~km}$ south-east of San Francisco and $15 \mathrm{~km}$ from the south end of San Francisco Bay. The airport serves domestic and international air carrier flights as well as general aviation. San José is the thirdlargest city in California and is part of the greater San Francisco Metropolitan Area, which has a total population of almost 8,000,000 people. San José's population has grown from 783,362 in 1990 to 1,000,536 persons in 2014. San José has a Mediterranean climate, with a dry season from May to October and a wet season from November to April. Mean annual rainfall is $37 \mathrm{~cm}$ and mean seasonal temperatures range from $10^{\circ}$ to $22^{\circ} \mathrm{C}$ (WRCC 2014).

The airport is flat, although elevation gradually increases from $12 \mathrm{~m}$ above mean sea level at the north end, to $20 \mathrm{~m}$ at the south end. The airfield encompasses approximately 425 ha, of which only about 134 ha were vegetated. The vegetated area consisted of 42 infields between paved runways and taxiways (Figure 2). Vegetation in the infields was a mixture of non-native grasses and annual weedy, herbaceous plants characteristic of the California annual grassland series (Sawyer and Keeler-Wolf 1995). During the wet season, vegetation was regularly mowed to a height of $10 \mathrm{~cm}$ or less. 


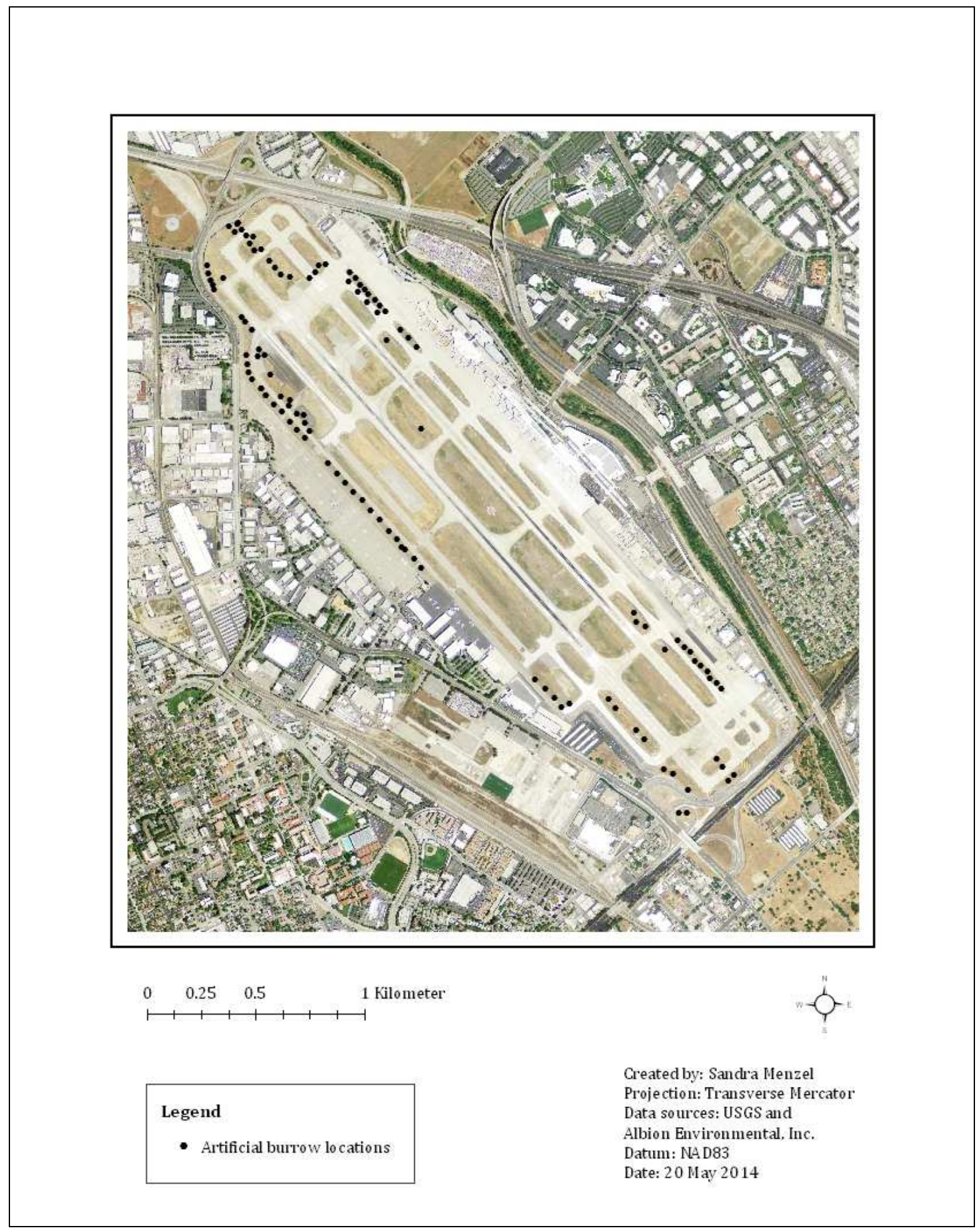

Figure 2. San José International Airport configuration and artificial burrow ( $\mathrm{n}=113$ ) locations for burrowing owls, 1990-2011. 
The airport, one of the largest remaining open grassland areas in the Santa Clara Valley, is surrounded by dense urban sprawl. This grassland "island" attracted a variety of resident and transient wildlife species, including at least 28 bird species (Table 1) and 12 small mammal species (Table 2). One of the most numerous diurnal mammal species at SJC was the California ground squirrel (Albion Environmental, Inc. 2010a).

Table 1. Common and scientific name of 28 bird species observed at San José International Airport during the Wildlife Hazard Assessment surveys from 1 July 2009 to 30 June 2010 (reprinted from Albion Environmental, Inc. 2010a).

\begin{tabular}{ll} 
Common name & Scientific name \\
\hline American crow & Corvus brachyrhynchos \\
American kestrel & Falco sparverius \\
American pipit & Anthus rubesens \\
Anna's hummingbird & Calypte anna \\
Barn swallow & Hirundo rustica \\
Black phoebe & Sayornis nigricans \\
Brewer's blackbird & Euphagus cyanocephalus \\
Burrowing owl & Athene cunicularia \\
California gull & Larus californicus \\
Canada goose & Branta canadensis \\
Common raven & Corvus corax \\
European starling & Sturnus vulgaris \\
Golden eagle & Aquila chrysaetos \\
Great blue heron & Ardea herodias \\
House finch & Carpodacus mexicanus \\
Killdeer & Charadrius vociferus \\
Loggerhead shrike & Lanius ludovicianus \\
Mallard & Anas platyrhynchos \\
Mourning dove & Zenaida macroura \\
Northern mockingbird & Mimus polyglottos \\
Red-tailed hawk & Buteo jamaicensis \\
Rock pigeon & Columba livia \\
Say's phoebe & Sayornis saya \\
Tree swallow & Tachycineta bicolor \\
Turkey vulture & Cathartes aura \\
Violet-green swallow & Tachycineta thalassina \\
Western meadowlark & Sturnella neglecta \\
Yellow-rumped warbler & Dendroica coronata \\
\hline \hline
\end{tabular}


Table 2. Common and scientific name of 12 mammal species incidentally observed at San José International Airport (reprinted from Albion Environmental, Inc. 2010a).

\begin{tabular}{ll} 
Common name & Scientific name \\
\hline Blacktail jackrabbit & Lepus califonicus \\
California ground squirrel & Spermophilus beecheyi \\
California vole & Microtis californicus \\
Domestic cat & Felis catus \\
Domestic dog & Canis lupus \\
Deer mouse & Peromyscus maniculatus \\
House mouse & Mus musculus \\
Mexican free-tailed bat & Tadarida brasiliensis \\
Norway rat & Rattus norvegicus \\
Opossum & Didelphis virginiana \\
Raccoon & Procyon lotor \\
Striped skunk & Mephitis mephitis \\
Valley pocket gopher & Thomomys bottae \\
\hline \hline
\end{tabular}

California ground squirrels occurred mainly in the northern and western portions of the airfield where the soil was loose and porous. In those areas, natural burrows were abundant and provided habitat for a resident population of burrowing owls. In other areas the soil was too hard and poorly drained, making it unsuitable for fossorial mammal activity. The soil types at SJC were a mixture of clay (65\%) and silt loam (35\%) (USDA 2014), and in many areas the soil had been modified and compacted from grading operations.

Ground squirrels attract large raptors, such as red-tailed hawks, which pose strike hazards to aircraft. To reduce bird strike hazards, the airport occasionally implemented ground squirrel control. Control methods included bait stations and fumigation. Generally, ground squirrel control reduces the number of potential nest and roost burrows for burrowing owls.

Active burrowing owl management at SJC began in 1990 when a nesting pair of 
owls was observed occupying a natural burrow in a construction area (Barclay 2007). The number of construction projects increased after the San José City Council approved the new airport Master Plan for long-term expansion in 1997. The need for airport expansion was confirmed in 2000 , when passenger traffic increased to an all-time high of 14.2 million passengers per year, mainly driven by the Silicon Valley technology boom.

To minimize the occurrence of nesting burrowing owls in construction areas in the future, Barclay wrote a Burrowing Owl Management Plan (Albion Environmental, Inc. 1997a) for the airport. This plan described how increased airport operations, maintenance, and construction could be integrated with longterm management and conservation of burrowing owls.

Mitigation measures included in the management plan required that each natural burrow occupied by nesting burrowing owls that was impacted by construction activities be replaced with two artificial burrows outside the construction area. Barclay (2008a) described the artificial burrow design used at SJC (Figure 3). 


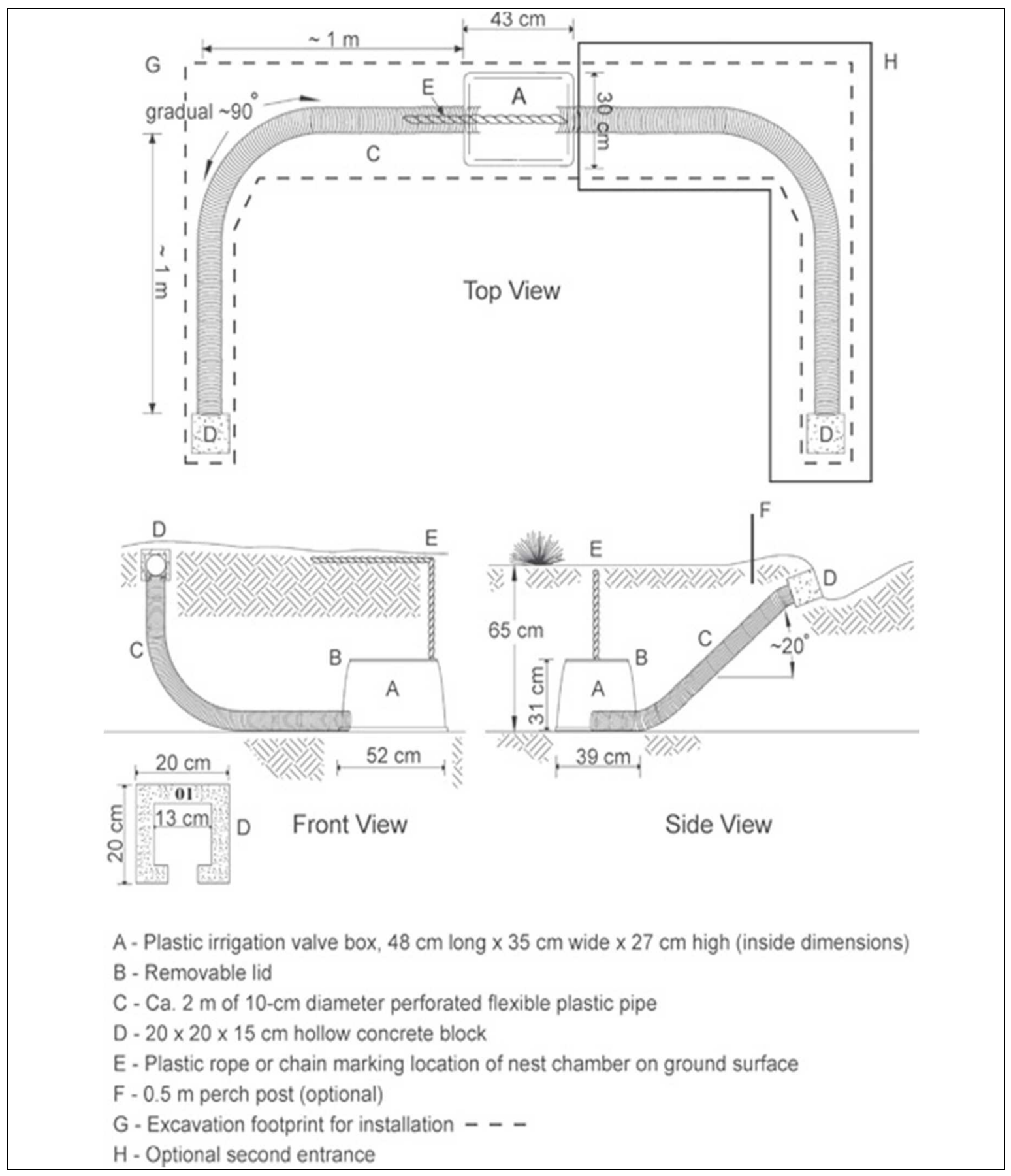

Figure 3. Artificial burrow design (reprinted from Barclay 2008a). 
During 1990-2009, 113 artificial burrows were installed to replace natural burrows intentionally closed in construction areas or near runways (Figure 2). The installation of artificial burrows was a dynamic process, starting with two burrows in late 1990 and incrementally increasing to a maximum of 71 artificial burrows in the ground and potentially available to owls. Some artificial burrows had to be replaced at a new location, either because they were in the way of further construction or the previous placement was unsuitable (e. g., erosion). Replacement burrows received a new designation number, thus the total number of artificial burrow installations $(n=113)$ exceeded the maximum number of artificial burrows actually in the ground $(n=71)$. All artificial burrows were installed at the ends of the runways and between taxiways paralleling the runways where strike hazards to aircraft were lowest (Figure 2) (Albion Environmental, Inc. 2010a).

\section{Sharpe Depot}

Sharpe Depot, a principal military supply depot, is located in the City of Lathrop in San Joaquin County, California (Figure 1), approximately $11 \mathrm{~km}$ south of Stockton. The depot covers 293 ha, measuring approximately $3 \mathrm{~km}$ long (north to south) and $1 \mathrm{~km}$ wide (Figure 4). Topography on the depot is flat with small contours (less than $1.5 \mathrm{~m}$ ) resulting from minor surface and road grading. Elevation gradually decreases from $8 \mathrm{~m}$ above mean sea level at the north end, to $6 \mathrm{~m}$ at the south end of the depot. Lathrop has a Mediterranean climate, with a dry season from May to October and a wet season from November to April. Mean annual 
rainfall is $30 \mathrm{~cm}$ and mean seasonal temperatures range from $9^{\circ}$ to $23^{\circ} \mathrm{C}$ (WRCC 2014).

Sharpe Depot contained 11 large (ranging from 1.2 ha to 7.3 ha) warehouses, approximately 80 smaller buildings, large barren storage areas, a decommissioned runway, and railroad tracks. Two teardrop-shaped railroad turn-around areas, termed the north and south "balloons," were located at each end of the facility (Figure 4). Areas between warehouses and buildings consisted of compacted soil bisected by railroad tracks and unpaved roads. In most areas (92\%) of the depot, the native soil was modified and altered with fill (USDA 2014). The soil types in the remaining areas were a mix of sandy loam (7\%) and loamy sand (1\%) (USDA 2014). Most of the ground surface was either barren or sparsely vegetated by invasive grasses and herbaceous plants characteristic of disturbed sites. The most common plant species were yellow starthistle (Centaurea solstitialis) and Bermuda grass (Cynodon dactylon).

California ground squirrels occurred throughout the study site where the soil was loose and porous; natural burrows in those areas were abundant. In other areas of the depot, the soil was compacted and poorly drained, making it unsuitable for fossorial mammal activity. Sharpe Depot occasionally implemented ground squirrel control, using rodenticides and bait stations.

In 1997, Barclay (Albion Environmental, Inc. 1997b) wrote a Burrowing Owl Management Plan for Sharpe Depot that included recommendations for avoiding and/or mitigating impacts to the burrowing owl population from long-term 
development. Based on this plan, 51 artificial burrows (Figure 3) were installed in February 1999 to replace natural burrows intentionally closed for a large warehouse construction project (Figure 4). 




Figure 4. Sharpe Depot configuration and artificial burrow $(n=51)$ locations for burrowing owls, 1999-2012. 


\section{Study Design}

\section{San José International Airport}

I analyzed data Albion biologists collected at SJC from 1990 through 2011, consisting of 14,088 records of burrowing owl observations. Each record contained an observation date, burrow identification number (ID), band status (banded, not banded, unknown), band ID, sex (male, female, or unknown), and age class (nestling, juvenile, adult, or unknown) of each owl observed.

Burrow ID refers to a serial number assigned to each natural burrow, artificial burrow, or non-burrow location where owls were observed. Band ID refers to an alphanumeric code on a color leg-band. Between 1996 and 2011, 831 burrowing owls (803 juveniles and 28 adults) at SJC were banded with a blue metal color band with a unique alphanumeric code (manufactured by Acraft Sign and Nameplate Company, Alberta, Canada) on one leg and a standard United States Fish and Wildlife Service band on the other leg. Information on artificial burrow installations, maintenance, and status (e. g., tunnel open, tunnel partially filled with soil, or tunnel entrance buried) were recorded in annual reports (Albion Environmental, Inc. 1990, 1991, 1992, 1993, 1994, 1995, 1996, 1997c, 1998a, 1999a, 2000a, 2001a, 2002a, 2003a, 2004a, 2005a, 2006a, 2007a, 2008a, 2009a, 2010b, 2011a)

Each annual report also included a figure and a table of all artificial and natural burrows occupied by nesting pairs of burrowing owls during that year and if pairs nested successfully or not. I searched the database records for banded owl sightings 
at these burrows during the nesting season from March through August, to determine which owl nested at an artificial or natural burrow and if it nested in the same burrow in subsequent years. To investigate how many of the artificial burrows were actually open and available for burrowing owls, I analyzed the maintenance records from 1990 through 2011.

\section{Sharpe Depot}

I analyzed data Albion biologists collected at Sharpe Depot from 1997 through 2012. Data included observation date, burrow ID, sex (male, female, or unknown), and age class (juvenile, adult, or unknown) of each owl observed. Each annual report (Albion Environmental, Inc. 1997d, 1998b, 1999b, 2000b, 2001b, 2002b, 2003b, 2004b, 2005b, 2006b, 2007b, 2008b, 2009b, 2010c, 2011b, 2012) included a figure of all artificial and natural burrows occupied by nesting pairs of burrowing owls during that year. Information on artificial burrow installation was provided in one annual report (Albion Environmental, Inc. 1999b) and artificial burrow status (e. g., tunnel open, tunnel partially filled with soil, or tunnel entrance buried) was recorded in two of the annual reports (Albion Environmental, Inc. 2005b, 2011b). Burrowing owls at Sharpe Depot were not banded.

\section{Data Collection}

\section{San José International Airport}

Since the 1980s, SJC has conducted a year-round wildlife-monitoring program designed to detect wildlife (primarily bird) strike hazards and to comply with Federal Aviation Administration (FAA) safety regulations. Since 1990, this program 
consisted of 6-minute point-counts of all wildlife observed at six locations around the airfield twice each month. Counts were usually conducted in the morning under favorable weather conditions conducive to observing birds.

During these point counts and while traveling between count locations, Albion biologists recorded the locations of all burrowing owls observed, with a serial number assigned to each natural burrow, artificial burrow (Appendix 1), and nonburrow locations. Burrowing owls were mostly observed from inside a parked motor vehicle with binoculars or a spotting scope. Biologists also recorded the age class (i. e., adult, nestling, juvenile) and sex (if known) of each owl and whether or not the owl was banded and the color band number (if readable) (Appendix 2).

During weekly focused burrowing owl surveys during the nesting season (i. e., March through August), Albion biologists recorded all artificial and natural burrows occupied by nesting pairs. Biologists determined if a burrow was occupied by a nesting pair based on behavioral observations at or near the burrow entrance, such as burrow maintenance (e. g., digging), courtship, copulation, or prey delivery; or signs of activity such as decoration, pellets, droppings, or prey remains. They observed nesting phenology at each burrow and, once fledgling owls emerged, banded all young raised in artificial burrows. Nestlings were caught by hand inside artificial burrows after removing the lid of the nest chamber (Barclay 2008). Biologists used a modified rubber garden hose to coax older nestlings out of the artificial burrow tunnels (Barclay et al. 2011). Any adult captured incidentally inside the burrow was banded as well, but no special effort was made to trap and 
band adult owls. Owls were released into the same burrow immediately after banding.

Opening each occupied artificial burrow for banding allowed biologists to count all owlets inside the burrow. Thus, the number of young raised at each artificial burrow was a complete count. The number of young raised at each natural burrow, however, was an estimate based on the maximum number of two to four week-old owlets observed at the burrow entrance during any one survey. Productivity rates at artificial and natural burrows were therefore statistically not comparable because data were collected using different methods (Gorman et al. 2003).

All artificial burrows were inspected annually before the start of the nesting season, and their status (e. g., tunnel open, tunnel partially filled with soil, or tunnel entrance buried) recorded. Artificial burrows that were located (i. e., not buried from erosion or fossorial mammal activity) received annual surface maintenance: vegetation and built-up soil were removed around the burrow entrance and the tunnel was inspected visually or with a probe to check if it was open. No special effort was made to clean the inside of the nest chambers. However, when nest chambers were opened to catch and band nestlings, then excess nesting material and soil were removed from the nest chamber.

\section{Sharpe Depot}

At Sharpe Depot, burrowing owl observations were recorded during five annual surveys at the height of the nesting season from May through July, usually in 
the early evening. Biologists recorded the locations of all burrowing owls observed; with a serial number assigned to each natural and artificial burrow location (Appendix 3). Burrowing owls were observed from inside a parked motor vehicle with binoculars or a spotting scope. Biologists also recorded the age class (i. e., adult or juvenile) and sex (if known) of each owl. A nesting pair was considered productive (successful) when one or more juveniles were sighted at the nest burrow.

All artificial burrows were inspected and their status (e. g., tunnel open, tunnel partially filled with soil, or tunnel entrance buried) recorded once in 2005 and again in 2011. Artificial burrows at Sharpe Depot were not maintained annually.

\section{Data Analysis}

I used data from annual reports (Albion Environmental, Inc. 1990, 1991, 1992, 1993, 1994, 1995, 1996, 1997c, 1997d, 1998a, 1998b, 1999a, 1999b, 2000a, 2000b, 2001a, 2001b, 2002a, 2002b, 2003a, 2003b, 2004a, 2004b, 2005a, 2005b, 2006a, 2006b, 2007a, 2007b, 2008a, 2008b, 2009a, 2009b, 2010b, 2010c, 2011a, 2011b, 2012) to identify all artificial and natural burrows occupied by nesting pairs each year for each study site, and I determined how many breeding seasons each artificial burrow was occupied. I also reviewed the maintenance records for each artificial burrow at both study sites to evaluate how many of the artificial burrows were actually open and available for burrowing owls.

I used nested independent t-tests to analyze if burrowing owls occupied 
annually-maintained artificial burrows (SJC) for a greater number of breeding seasons than in unmaintained burrows (Sharpe Depot). Because of the disparity in the number of burrows at each location (i. e., 113 burrows at SJC and 51 burrows at Sharpe Depot), I created 15 datasets each containing all 51 artificial burrows at Sharpe Depot and 51 different randomly selected artificial burrows from SJC. I performed chi-squared goodness-of-fit tests for each of the study sites to examine whether the nesting success rate was significantly different between artificial and natural burrows.

I selected all database records that contained banded burrowing owl resightings at SJC. For each owl banded as a nestling, I conducted a query that resulted in all records of re-sightings during the following nesting seasons (MarchAugust). The query results showed whether the owl was sighted at an artificial or natural burrow during subsequent nesting seasons and if it occupied the same burrow or a different burrow during subsequent nesting seasons.

For further analysis of philopatry and nest-site fidelity, I used ArcGIS 10.1 to measure the distances of natal dispersal and breeding dispersal movements of each banded owl that was re-sighted. I defined natal dispersal as the straight-line distance between the natal burrow and the next observed nest burrow in a subsequent year, and breeding dispersal as the distance between the breeding sites of successive years (Korpimäki et al. 1987, Newton 2008). Additionally, I analyzed compass directions of natal dispersal and breeding dispersal movements. 


\section{RESULTS}

\section{Burrow Occupancy and Maintenance}

\section{San José International Airport}

Occupancy rates of artificial burrows each nesting season (March-August), ranged from a high of $67 \%$ in 1991 and 1992 when two out of three artificial burrows were occupied, to a low of $10 \%$ in 2009 when seven out of 71 artificial burrows were occupied (Figure 5). On average, 26\% (SD = 17) of artificial burrows were occupied 1990-2011.

The sum of all artificial burrows in the ground each year 1990-2011, totaled 858 burrow-years. Burrow entrances (maintained annually) and tunnels were actually open for 687 burrow-years, or $80 \%$ of burrow-years. The close relationship between the number of artificial burrows in the ground and the number of artificial burrows actually open, decreased after 2003, with a low in 2009 of $46 \%$ of artificial burrows in the ground actually being open (Figure 5). 


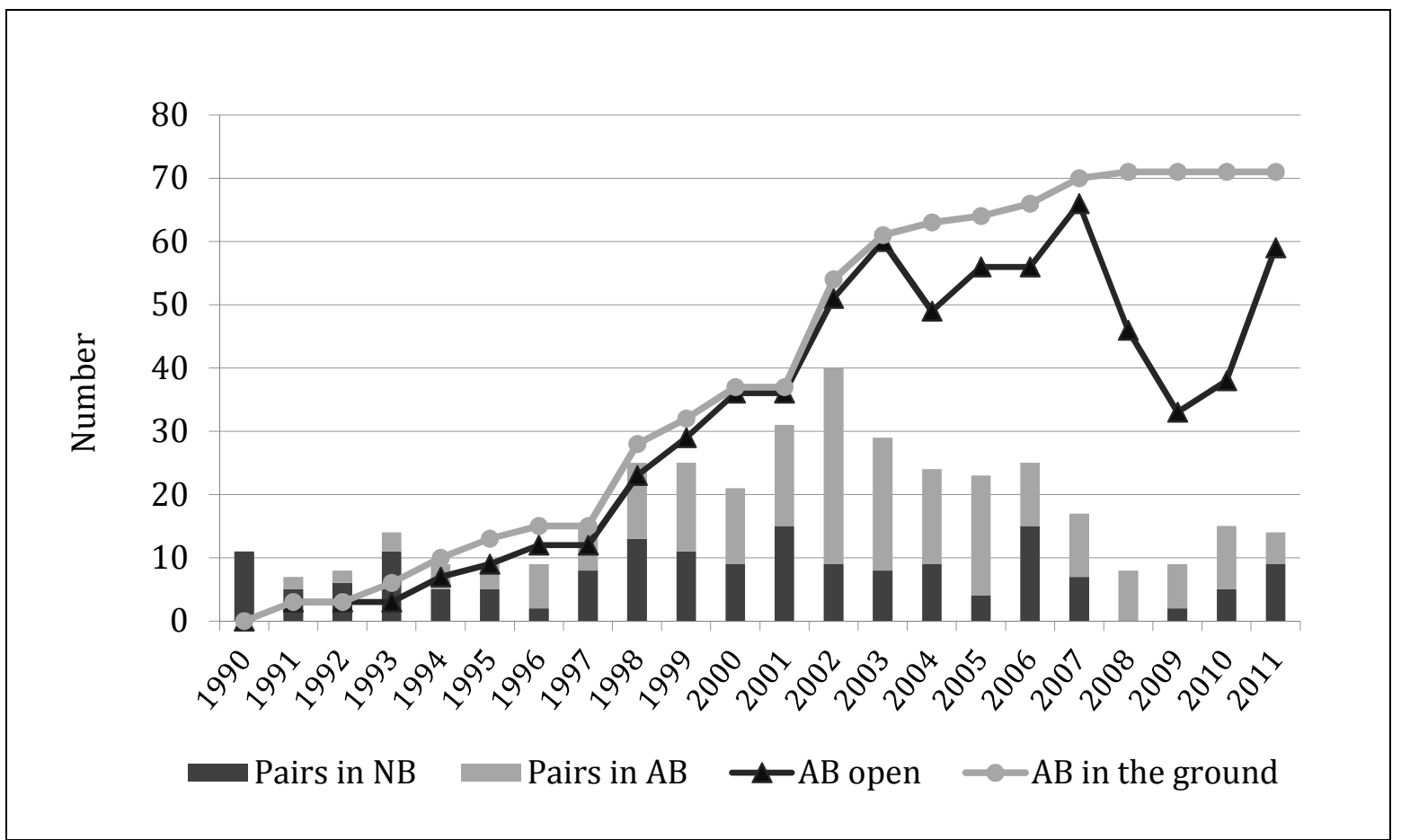

Figure 5. Number of artificial burrows (AB) in the ground each year, compared to artificial burrows with entrance and tunnel actually open, and artificial burrows and natural burrows (NB) occupied by nesting burrowing owls at San José International Airport, 19902011.

\section{Sharpe Depot}

At Sharpe Depot, artificial burrows were occupied for six nesting seasons after initial installation 1999-2001 and 2003-2005, with no pairs occupying artificial burrows in 2002 (Figure 6). Occupancy rates of the 51 non-maintained artificial burrows ranged from a high of $10 \%(n=5)$ in 2000 and 2001 to a low of $4 \%(n=2)$ in 2005 (Figure 6). On average, 3\% (SD = 4) of artificial burrows were occupied 1999-2012. Results of artificial burrow inventories in 2005 and 2011 showed that of the 51 artificial burrows installed in 1999, 22 (43\%) were open in 2005 and only one (2\%) in 2011 (Figure 6). 


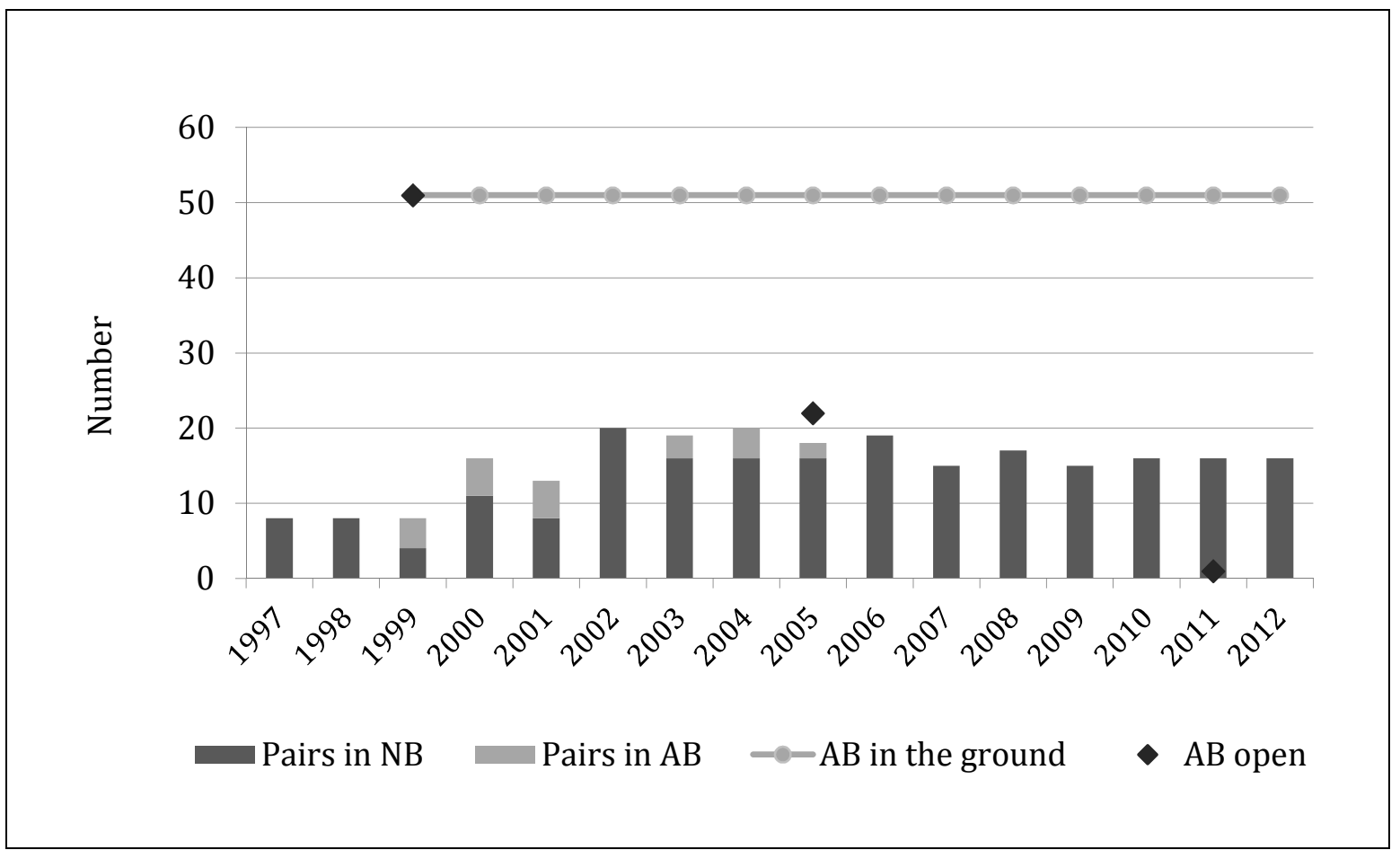

Figure 6. Number of artificial burrows (AB) in the ground each year, compared to artificial burrows with entrance and tunnel actually open, and artificial burrows and natural burrows (NB) occupied by nesting burrowing owls at Sharpe Depot, 1997-2012. Artificial burrows $(n=51)$ were installed in February 1999, and inspected in 2005 and 2011.

The results of t-tests showed that maintained burrows at SJC were occupied for a significantly ( $\mathrm{p} \leq 0.003$ ) greater number of nesting seasons than nonmaintained burrows at Sharpe Depot. Burrows at SJC were occupied for a mean of 1.90 nesting seasons $(\mathrm{SD}=2.04)$, compared to a mean of 0.45 nesting seasons $(\mathrm{SD}=$ 0.97) at Sharpe Depot.

At SJC, 24\% of artificial burrows were never occupied (Figure 7 and 8), compared to $71 \%$ at Sharpe Depot (Figure 7 and 9). Thirty-one percent of artificial burrows were occupied at SJC for only one nesting season and $20 \%$ for two nesting seasons, dropping to $8 \%$ for three nesting seasons of occupancy. One noteworthy 
outlier was artificial burrow AB01 (Figure 2), the first artificial burrow ever installed at SJC, which was occupied for 14 of the 15 nesting seasons that it was available (Figure 7). At Sharpe Depot, 24\% of artificial burrows were occupied for one nesting season, one (2\%) burrow was occupied two nesting seasons, one (2\%) burrow four nesting seasons, and one (2\%) burrow five nesting seasons (Figure 7).



No. of nesting seasons occupied

$$
\text { - SJC ( } \mathrm{n}=113) \quad \text { Sharpe Depot }(\mathrm{n}=51)
$$

Figure 7. Comparison of the number of nesting seasons artificial burrows were occupied by pairs of burrowing owls at San José International Airport (SJC) and Sharpe Depot, 19912012. 


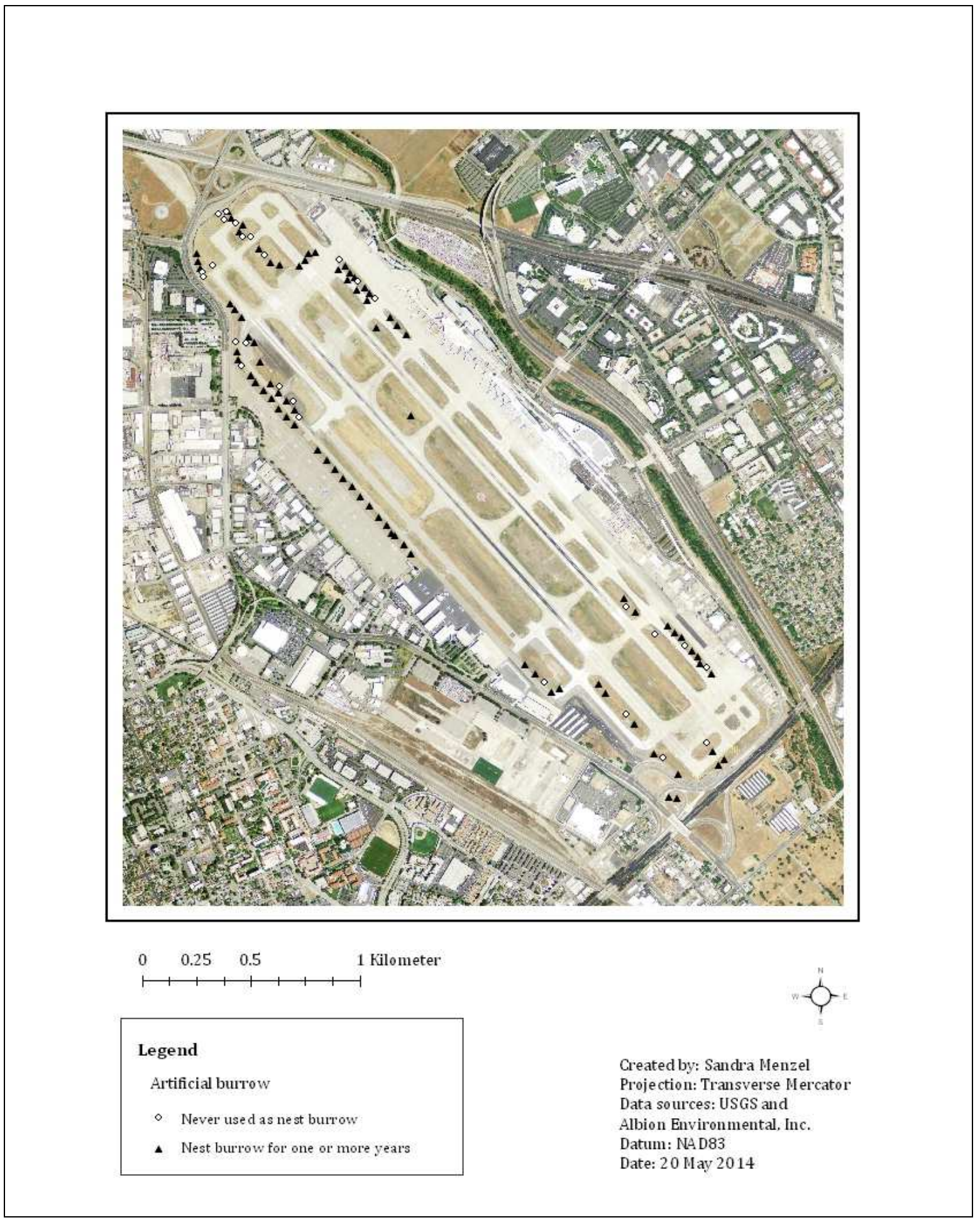

Figure 8. Locations of used and unused artificial burrows $(n=113)$ for burrowing owls nesting at San José International Airport, 1990-2011. Almost one quarter ( $n=27)$ of burrows were never used as nest burrows. 


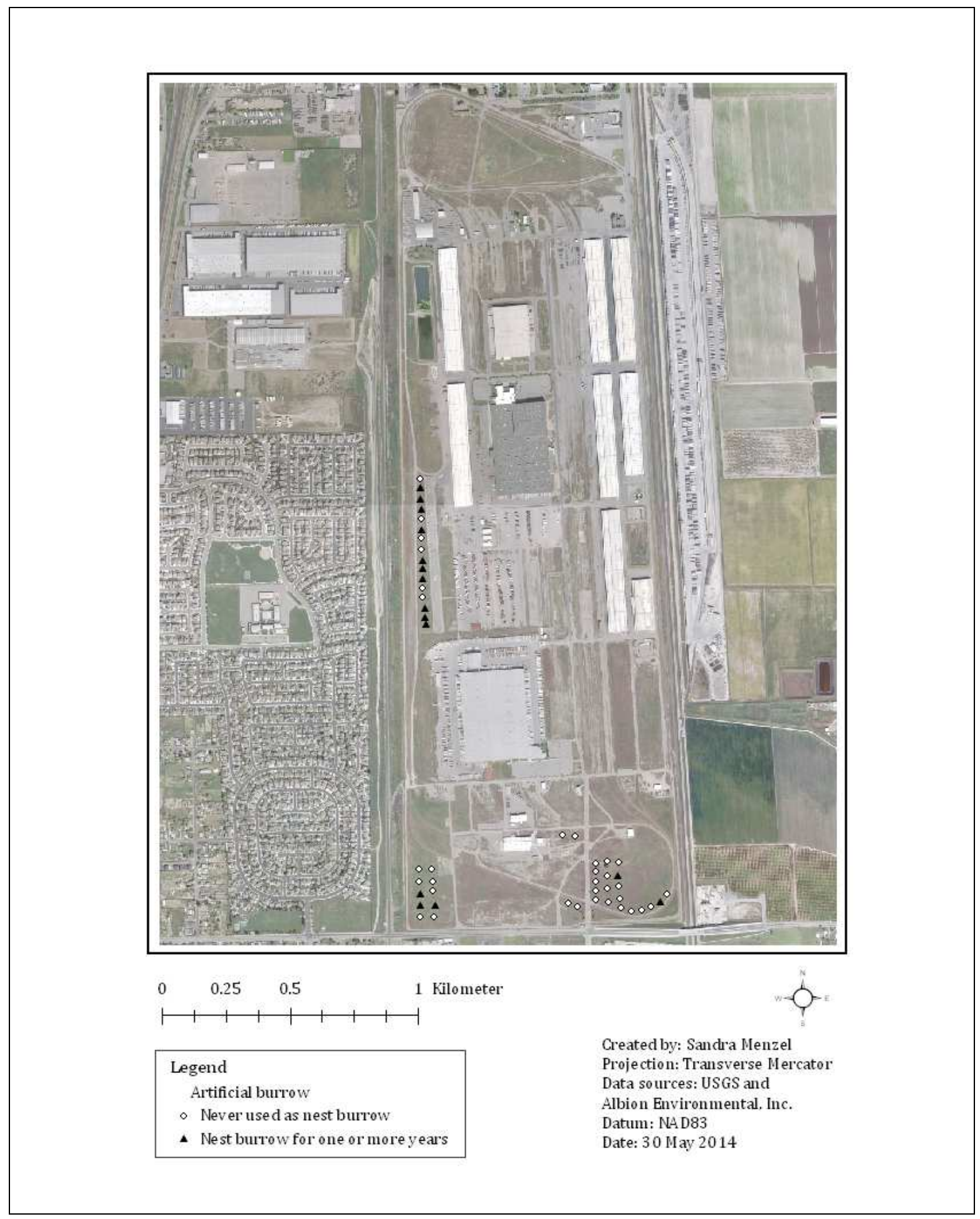

Figure 9. Locations of used and unused artificial burrows $(n=51)$ for burrowing owls nesting at Sharpe Depot, 1999-2012. Almost three-quarters $(n=36)$ were never used as nest burrows. 


\section{Nesting Success and Burrow Choice}

\section{San José International Airport}

The result of a chi-squared goodness-of-fit test showed no significant difference in nesting success ( $\geq 1$ fledgling/pair) at artificial burrows compared to natural burrows $\left(\chi^{2}=2.75, \mathrm{df}=3, \mathrm{p}>0.05\right)$. Nesting success in natural burrows was 76\%, compared to $83 \%$ in artificial burrows (Table 3).

Table 3. Nesting success ( $\geq 1$ fledgling/pair) of burrowing owls in natural (NB) and artificial (AB) burrows at San José International Airport, 1990-2011.

\begin{tabular}{lcc}
$\mathrm{n}=388$ & $\mathrm{NB}(\%)$ & $\mathrm{AB}(\%)$ \\
\hline Productive pairs & $129(76)$ & $182(83)$ \\
Non-productive pairs & $40(24)$ & $32(15)$ \\
Unknown & $0(0)$ & $5^{*}(2)$ \\
\hline Total & 169 & 219
\end{tabular}

*In 2011, Albion Environmental, Inc. biologists recorded data only through June 30, at which time the nesting success for five pairs remained undetermined.

During 1991-2011, 219 (58\%) pairs at SJC occupied artificial burrows during the nesting season, while 158 (42\%) occupied natural burrows (Figure 5 and 10). The 120 burrowing owls raised in artificial burrows and re-sighted at SJC in subsequent years, made a total of 182 nesting attempts: 127 (70\%) in artificial burrows and $55(30 \%)$ in natural burrows. 




Figure 10. Natural burrow locations $(n=48)$ occupied by nesting burrowing owls raised in artificial burrows at San José International Airport, 1990-2011. 


\section{Sharpe Depot}

The result of a chi-squared goodness-of-fit test showed no significant difference in nesting success ( $\geq 1$ fledgling/pair) between artificial and natural burrows $\left(\chi^{2}=6.76, d f=3, p>0.05\right)$. Nesting success in natural burrows was $75 \%$, compared to $96 \%$ in artificial burrows during those years that artificial burrows were occupied, 1999-2001 and 2003-2005 (Table 4).

Table 4. Nesting success ( $\geq 1$ fledgling/pair) of burrowing owls in natural (NB) and artificial (AB) burrows at Sharpe Depot, during those years that artificial burrows were occupied, 1999-2001 and 2003-2005.

\begin{tabular}{lcc}
$\mathrm{n}=94$ & NB $(\%)$ & AB (\%) \\
\hline Productive pairs & $53(75)$ & $22(96)$ \\
Non-productive pairs & $18(25)$ & $1(4)$ \\
\hline Total & 71 & 23
\end{tabular}

During 1999-2012, 205 (90\%) pairs occupied natural burrows during the nesting season, whereas 23 (10\%) pairs occupied artificial burrows, with a maximum of 38\% (5 out of 13) of pairs occupying artificial burrows in 2001 (Figure 6). During those six years that artificial burrows were occupied, 24\% (23 out of 94) of pairs occupied artificial burrows. In 1999, during the first nesting season after installation, 50\% (4 out of 8) of pairs occupied artificial burrows, declining to $11 \%$ (2 out of 18) in 2005 (Figure 6).

\section{Nest-site Fidelity and Natal Philopatry}

At SJC, 120 (15\%) of 803 burrowing owls raised in artificial burrows, occupied burrows at the airport during the following nesting season. Of these 120 
birds, 82 (68\%) used artificial burrows, whereas 38 (32\%) used natural burrows (Figure 11). Forty-six (6\%) of all 803 burrowing owls raised in artificial burrows were re-sighted at artificial burrows at SJC during two or more nesting seasons and $13(2 \%)$ in natural burrows. Of those owls re-sighted in artificial burrows, 22 (48\%) switched artificial burrows between years (11 males, 10 females, 1 unknown), 17 (37\%) used the same artificial burrow ( 9 males, 7 females, 1 unknown), and seven (15\%) did both: used the same artificial burrow for $\geq 2$ years and switched to other artificial burrows for $\geq 1$ years ( 4 males, 3 females).

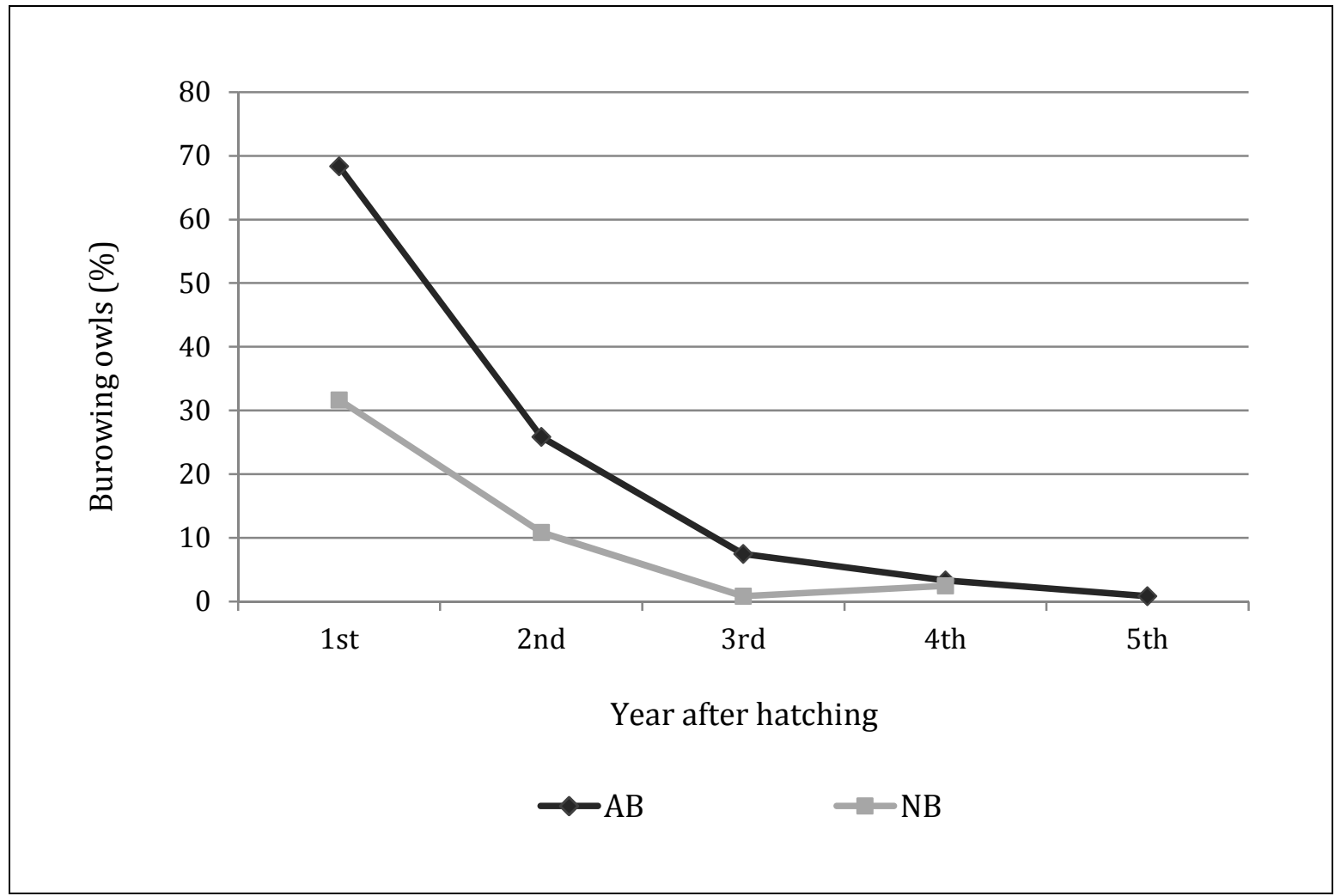

Figure 11. Comparison of artificial (AB) and natural burrow (NB) occupancy from year to year post-hatching by burrowing owls $(n=120)$ raised in artificial burrows and re-sighted during the nesting season at San José International Airport, 1990-2011. 
Four (3\%) of the120 re-sighted burrowing owls used their natal burrow during their first breeding season (2 males, 1 female, 1 unknown) (Figure 12). One male owl was not sighted during the first breeding season post-fledging, but he returned to his natal burrow for nesting the following year. Of those owls that used a burrow other than their natal burrow, $20 \%$ occupied a burrow within $499 \mathrm{~m}$ of the natal burrow for their first nesting attempt, and 32\% used a burrow 500-999 m away. The remaining burrowing owls (48\%) dispersed farther than $1 \mathrm{~km}$ (Figure 12 and 13). Eight (7\%) of the 120 owls were re-sighted using natural burrows off the airport within $15 \mathrm{~km}$ of their natal burrow during their first nesting attempt. Offairport locations included: Moffett Federal Airfield in Mountain View, along Devcon Court and near the intersection of Tully Road/Capitol Expressway in San José, and Santa Clara Golf and Tennis Club in Santa Clara.

Of the 46 owls that were re-sighted at artificial burrows during a second breeding season, $34 \%$ used the same burrow as the previous year, $57 \%$ used a burrow within $499 \mathrm{~m}$ of the previous burrow, and 9\% dispersed farther than $500 \mathrm{~m}$. Of those owls re-sighted for a third, fourth, or fifth breeding season, $26 \%$ occupied the same nest burrow that they had used the previous year. Thirty-one percent stayed within $499 \mathrm{~m}$ of the previous burrow, and 24\% dispersed 500-999 m (Figure 12 and 13). 


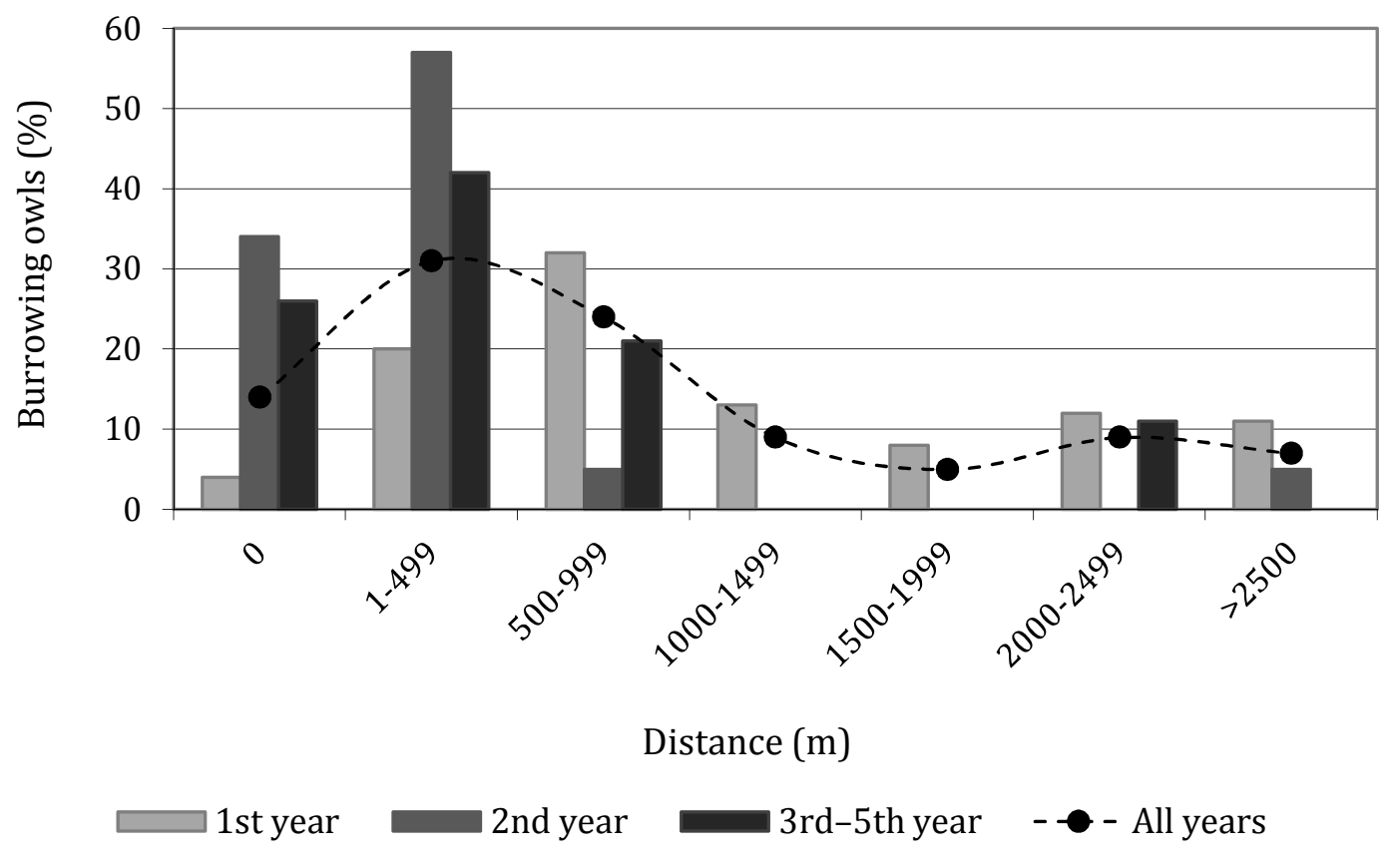

Figure 12. Natal (light grey bars) and breeding dispersal (darker shading) movements by burrowing owls $(\mathrm{n}=120)$ raised in artificial burrows and re-sighted at San José International Airport, 1990-2011. First-year movement was the distance measured from natal burrow to first nest burrow, and subsequent movements were measured from nest burrows used the previous year. The farthest recorded movement was $\sim 15 \mathrm{~km}$ to an offairport location.

Of the 182 nesting attempts of 120 burrowing owls raised in artificial burrows, $14 \%(n=25)$ occurred at the same burrow (i. e., owls did not disperse from their natal burrow or previous nest burrow), while $86 \%(n=157)$ occurred in a different burrow than occupied the previous year. The directions of these movements (natal and breeding dispersal) were clearly influenced by the shape of the airfield, as well as the locations of artificial and natural burrows (Table 5, Figure 13). The directions of almost half (48\%) of the dispersal movements from one nesting season to the next were toward the second quadrant $\left(270-359^{\circ}\right)$ (Table 5 , Figure 13). Only three burrowing owls were never observed using a burrow other 
than their natal burrow; two owls occupied their natal burrow each for one nesting season post-hatching, and one owl used the natal burrow for two nesting seasons.

Table 5. Compass directions of natal and breeding dispersal movements $(n=157)$ of 117 burrowing owls raised in artificial burrows at San José International Airport, 1990-2011.

\begin{tabular}{ll} 
Compass direction $\left(^{\circ}\right)$ & $\begin{array}{l}\text { Burrowing owl } \\
\text { movements }(\%) \\
(\mathrm{n}=157)\end{array}$ \\
\hline $0-89$ & 8 \\
$90-179$ & 33 \\
$180-269$ & 11 \\
$270-359$ & 48
\end{tabular}




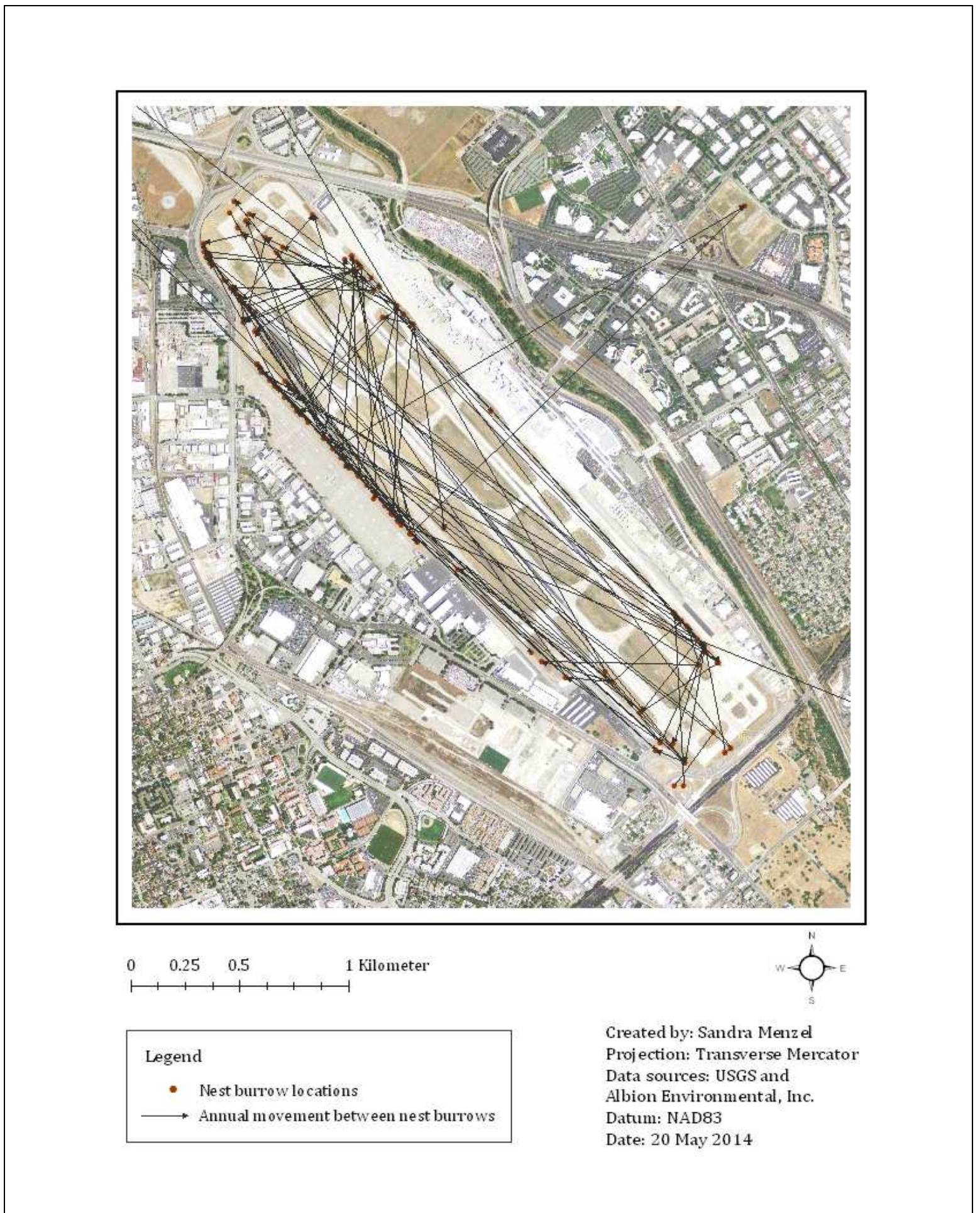

Figure 13. Natal and breeding dispersal movements by burrowing owls $(n=117)$ raised in artificial burrows at San José International Airport, 1990-2011. The farthest movement was $\sim 15$ $\mathrm{km}$ to an off-airport location. 


\section{DISCUSSION}

\section{Burrow Occupancy and Maintenance}

The results of this study confirmed Collins and Landry's (1977) initial observations that burrowing owls readily occupied newly installed artificial burrows, but that burrows may fill with soil from fossorial mammal activity, or erosion and silting during winter storms. Burrows require maintenance in order to be available for longer-term occupancy by burrowing owls.

Belthoff and Smith (2003) found that with periodic maintenance and cleaning, artificial burrows remained suitable for use by burrowing owls during their 5-year study; however, they did not provide a specific maintenance protocol or schedule. Their study also lacked a control group of unmaintained artificial burrows to compare the effects of maintenance versus non-maintenance on occupancy rates.

My research results showed that artificial burrows receiving surface maintenance (i. e., removal of vegetation and built-up soil around the burrow entrance) at SJC were occupied for a significantly greater number of nesting seasons $(\overline{\mathrm{x}}=1.90, \mathrm{SD}=2.04)$ than were the non-maintained artificial burrows at Sharpe $\operatorname{Depot}(\overline{\mathrm{x}}=0.45, \mathrm{SD}=0.97)$. Nevertheless, even with surface maintenance, occupancy rates at SJC dropped from 31\% during the first year to $8 \%$ during the third year post-installation. Cleaning or reinstallation of the entire burrow system approximately every three years appears to be crucial for longer-term use.

Soil texture greatly impacts the longevity of burrows and probably affects artificial and natural burrows similarly. Green and Anthony (1989) reported that 
$46 \%(n=85)$ of natural burrows located in loamy sand were silted in by the next nesting season, but that none of 13 nest burrows in silty loam were silted in. Holmes et al. (2003) found that natural burrows were available for owls the longest in sandy loam and collapsed most frequently in loamy sand. At SJC, where the soil types were a mixture of clay and silt loam, artificial burrows did not erode as quickly as compared to Sharpe Depot, where the soil types included sandy loam and loamy sand.

Rich (1984) reported that natural burrows in rock outcrops in Idaho were reused more often $(49 \%, \mathrm{n}=113)$ than burrows in soil mounds $(31 \%, \mathrm{n}=159)$. Burrows in rock outcrops were never destroyed during his study period and he compared their durability to artificial burrows. Nonetheless, Rich (1984) found that even though burrows were not destroyed, they tended to be occupied for 1-3 years followed by years of non-use, indicating that other factors may lead to burrow abandonment, such as over-wintering ectoparasite infestation (Smith and Belthoff 2001c), previous nest failure (Catlin et al. 2005, DeSmet 1997), or changes in nearby prey/predator abundance (Wellicome et al. 1997). Rich's (1984) findings concur with observations at both of my study sites; of all artificial burrows that were ever occupied by a nesting pair, 78\% at SJC and 87\% at Sharpe Depot were occupied for no more than three years.

\section{Nesting Success and Burrow Choice}

Average nesting success at artificial and natural burrows at both of my study sites was statistically not significantly different. Although not significant, average 
nesting success ( $\geq 1$ fledgling/pair) in artificial burrows at SJC (1990-2011), was 7\% higher than in natural burrows. The difference was $4 \%$ less than Barclay et al. (2011) reported 1990-2006 at the same study location. At Sharpe Depot (19992001 and 2003-2005) the average nesting success in artificial burrows was $21 \%$ higher than in natural burrows. These findings are comparable with results from other studies (Botelho and Arrowood 1998, Smith and Belthoff 2001b, Smith et al. 2005) that also found similar nesting success rates at both burrow types.

The hypothesis that burrowing owls that were raised in artificial burrows will nest in artificial burrows more frequently than in natural burrows was supported: 120 burrowing owls raised in artificial burrows at SJC made a total of 182 nesting attempts: 127 in artificial burrows (70\%) and 55 in natural burrows (30\%). Riding (2010) observed at his study site in southwestern Idaho that burrowing owls rarely used natural burrows for nesting in areas where artificial burrows were present, possibly because of a shortage of suitable natural burrows. At SJC, however, natural burrows were abundant and seemingly not a limiting factor, indicating that owls were preferentially selecting artificial burrows. Nest type imprinting as described by Brown and Collopy (2013) may occur to some degree, but clearly does not prevent occupancy of natural burrows by owls raised in artificial burrows.

\section{Nest-site Fidelity and Natal Philopatry}

The main reasons for nest-site fidelity and natal philopatry in individuals of many species are avoidance of energy expenditure from movement and familiarity 
with the area, including both its resources and hazards (Sanz-Aguilar 2012). Of 803 burrowing owls raised in artificial burrows at SJC 1990-2011, 120 (15\%) nested at SJC during the subsequent breeding season. This return rate was comparable to the $16 \%(n=124)$ return rate observed for another non-migratory population of burrowing owls in the Imperial Valley in California (Rosenberg and Haley 2004), and higher than the $8 \%$ rate reported for a migratory population in Colorado (Lutz and Plumpton 1999). In general, return rates are influenced by mortality and emigration, and migration might decrease the benefits of returning to a familiar nest site (Lutz and Plumpton 1999, Rosenberg and Haley 2004).

This study showed that burrowing owls nested in a different artificial burrow the following breeding season more often than in the same artificial burrow. Of 46 burrowing owls raised in artificial burrows that nested in artificial burrows at SJC for two or more nesting seasons, 22 (48\%) switched artificial burrows between breeding seasons (11 males, 10 females, 1 unknown), 17 (37\%) used the same artificial burrow ( 9 males, 7 females, 1 unknown), and seven (15\%) did both: used the same artificial burrow for $\geq 2$ years and switched to other artificial burrows for $\geq 1$ years ( 4 males, 3 females). Nest-site fidelity at SJC was not sex biased as Martin (1973), Wellicome et al. (1997), and Millsap and Bear (1997) observed at their study sites, where males reused former nest territories more frequently than females. Lutz and Plumpton (1999) also did not find a strong sex bias; of those birds that returned to former nest sites 19\% were male and $14 \%$ female. 
Similarly, natal philopatry at SJC also did not appear to be sex biased as suggested by Liberg and von Schantz (1985) and Wellicome et al. (1997), although the sample size in my study was too small for conclusive results. Only four (3\%) of the owls ( 2 males, 1 female, 1 unknown) used their natal burrow the subsequent year. One additional male was not sighted during the following breeding season, but he returned to his natal burrow for nesting the second year post-fledging.

Of the owls that dispersed from their natal burrow, 52\% were re-sighted nesting in a burrow $\leq 1 \mathrm{~km}$ from their natal burrow for their first nesting attempt. Owls that nested at SJC during the subsequent breeding season $(n=46)$ did not disperse as frequently or as far; $34 \%$ nested in the same burrow as the previous year, and $57 \%$ used a burrow within $499 \mathrm{~m}$ of the previous burrow. Wellicome et al. (1997) reported similar results from Saskatchewan, with first-year birds showing less nest-site fidelity than adults, though juvenile males were more philopatric than females. Understanding the extent of natal dispersal at managed sites is important because of its role in population dynamics and the colonization of unoccupied areas (Catlin and Rosenberg 2014).

The tendency for a northwesterly direction in natal and breeding dispersal at SJC was most likely due to the shape of the airport and the availability of natural and artificial burrows on the airfield. King and Belthoff (2001) found a tendency for southward movement during post-fledging dispersal in a migratory population in Idaho, which corresponded with the general direction of migration, but was more likely in response to higher quality habitat south of the study site. 


\section{MANAGEMENT AND CONSERVATION IMPLICATIONS}

Artificial burrows at SJC and Sharpe Depot were most attractive for burrowing owls during the first nesting season after installation. Annual surface maintenance at and around burrow entrances seemed to promote longer-term and higher occupancy rates of nesting owls at SJC. Even with annual surface maintenance, occupancy rates of artificial burrows steeply declined after two years. Thus, for longer-term mitigation, the entire burrow system may need to be cleaned or reinstalled approximately every three years. Although the installation of artificial burrows may be a useful short-term management tool, the presence and protection of fossorial mammals as the key provider of abundant natural burrows should remain a priority in any area managed for burrowing owls (Ronan 2002, Ronan and Rosenberg 2014).

Soil texture greatly impacts the longevity of artificial burrows (Rich 1984, Green and Anthony 1989, Holmes et al. 2003) and, in conjunction with the amount of precipitation, will influence the level, type, and timing of maintenance at different management sites. Sandier soils, which are prone to erosion, combined with the lack of maintenance of artificial burrows at Sharpe Depot appeared to contribute to shorter-term and lower occupancy rates, compared to SJC where soil types contained more clay. An evaluation of soil types at management sites may help to determine the appropriate design and maintenance of artificial burrows.

The number of artificial burrows at a management site must be sufficient to provide opportunities for burrowing owls to move between nest burrows from year 
to year, and to disperse to satellite burrows, especially when young emerge during the nesting season (Plumpton and Lutz 1993, Desmond and Savidge 1999, Poulin et al. 2005, Crowe and Longshore 2013, Ronan and Rosenberg 2014). Almost half (48\%) of the burrowing owls raised in artificial burrows at SJC and re-sighted during two or more nesting seasons, occupied different artificial burrows from one year to the next. Consequently, if artificial burrows are installed to mitigate the closure of natural burrows, replacement of natural burrows should occur at a rate of at least 1:3 for every closed burrow previously occupied by nesting owls. The ideal nest density at a management site will depend on available food resources in the surrounding foraging habitat.

Although I did not specifically quantify vegetation management and its effect on artificial burrow occupancy, vegetation management was an imperative prerequisite for the presence of burrowing owls at both study sites. Vegetation at SJC and Sharpe Depot was maintained short, providing favorable nesting and foraging habitat conditions for burrowing owls over the long-term. Burrowing owls require short vegetation around their nest burrows (Haug et al. 1993) and keeping an area surrounding artificial burrows mowed or grazed is essential for successful management. The optimal timing and extent of vegetation management will vary at different management sites and from year to year.

The results of this study showed that the installation of artificial burrows for burrowing owls can be an effective short-term mitigation tool. Burrowing owls chose to occupy artificial burrows more frequently than natural burrows and 
nesting success was slightly higher. However, the occupancy rates of artificial burrows diminished significantly only one year post-installation and cleaning or reinstallation of the entire burrow system is essential for longer-term mitigation.

To keep every cog and wheel is the first precaution of intelligent tinkering. --Leopold 1966 


\section{LITERATURE CITED}

Albion Environmental, Inc. 1990. Burrowing owl monitoring and management; annual report. San José International Airport. Unpublished report.

Albion Environmental, Inc. 1991. Burrowing owl monitoring and management; annual report. San José International Airport. Unpublished report.

Albion Environmental, Inc. 1992. Burrowing owl monitoring and management; annual report. San José International Airport. Unpublished report.

Albion Environmental, Inc. 1993. Burrowing owl monitoring and management; annual report. San José International Airport. Unpublished report.

Albion Environmental, Inc. 1994. Burrowing owl monitoring and management; annual report. San José International Airport. Unpublished report.

Albion Environmental, Inc. 1995. Burrowing owl monitoring and management; annual report. San José International Airport. Unpublished report.

Albion Environmental, Inc. 1996. Burrowing owl monitoring and management; annual report. San José International Airport. Unpublished report.

Albion Environmental, Inc. 1997a. Burrowing Owl Management Plan. San José International Airport. Unpublished report.

Albion Environmental, Inc. 1997b. Burrowing Owl Management Plan. Sharpe Depot. Unpublished report.

Albion Environmental, Inc. 1997c. Burrowing owl monitoring and management; annual report. San José International Airport. Unpublished report.

Albion Environmental, Inc. 1997d. Annual burrowing owl breeding census at Sharpe Depot. Defense Distribution Depot San Joaquin - Sharpe Site. Unpublished report.

Albion Environmental, Inc. 1998a. Burrowing owl monitoring and management; annual report. San José International Airport. Unpublished report.

Albion Environmental, Inc. 1998b. Annual burrowing owl breeding census at Sharpe Depot. Defense Distribution Depot San Joaquin - Sharpe Site. Unpublished 
report.

Albion Environmental, Inc. 1999a. Burrowing owl monitoring and management; annual report. San José International Airport. Unpublished report.

Albion Environmental, Inc. 1999b. Annual burrowing owl breeding census at Sharpe Depot. Defense Distribution Depot San Joaquin - Sharpe Site. Unpublished report.

Albion Environmental, Inc. 2000a. Burrowing owl monitoring and management; annual report. San José International Airport. Unpublished report.

Albion Environmental, Inc. 2000b. Annual burrowing owl breeding census at Sharpe Depot. Defense Distribution Depot San Joaquin - Sharpe Site. Unpublished report.

Albion Environmental, Inc. 2001a. Burrowing owl monitoring and management; annual report. San José International Airport. Unpublished report.

Albion Environmental, Inc. 2001b. Annual burrowing owl breeding census at Sharpe Depot. Defense Distribution Depot San Joaquin - Sharpe Site. Unpublished report.

Albion Environmental, Inc. 2002a. Burrowing owl monitoring and management; annual report. San José International Airport. Unpublished report.

Albion Environmental, Inc. 2002b. Annual burrowing owl breeding census at Sharpe Depot. Defense Distribution Depot San Joaquin - Sharpe Site. Unpublished report.

Albion Environmental, Inc. 2003a. Burrowing owl monitoring and management; annual report. San José International Airport. Unpublished report.

Albion Environmental, Inc. 2003b. Annual burrowing owl breeding census at Sharpe Depot. Defense Distribution Depot San Joaquin - Sharpe Site. Unpublished report.

Albion Environmental, Inc. 2004a. Burrowing owl monitoring and management; annual report. San José International Airport. Unpublished report.

Albion Environmental, Inc. 2004b. Annual burrowing owl breeding census at Sharpe Depot. Defense Distribution Depot San Joaquin - Sharpe Site. Unpublished report. 
Albion Environmental, Inc. 2005a. Burrowing owl monitoring and management; annual report. San José International Airport. Unpublished report.

Albion Environmental, Inc. 2005b. Annual burrowing owl breeding census at Sharpe Depot. Defense Distribution Depot San Joaquin - Sharpe Site. Unpublished report.

Albion Environmental, Inc. 2006a. Burrowing owl monitoring and management; annual report. San José International Airport. Unpublished report.

Albion Environmental, Inc. 2006b. Annual burrowing owl breeding census at Sharpe Depot. Defense Distribution Depot San Joaquin - Sharpe Site. Unpublished report.

Albion Environmental, Inc. 2007a. Burrowing owl monitoring and management; annual report. San José International Airport. Unpublished report.

Albion Environmental, Inc. 2007b. Annual burrowing owl breeding census at Sharpe Depot. Defense Distribution Depot San Joaquin - Sharpe Site. Unpublished report.

Albion Environmental, Inc. 2008a. Burrowing owl monitoring and management; annual report. San José International Airport. Unpublished report.

Albion Environmental, Inc. 2008b. Annual burrowing owl breeding census at Sharpe Depot. Defense Distribution Depot San Joaquin - Sharpe Site. Unpublished report.

Albion Environmental, Inc. 2009a. Burrowing owl monitoring and management; annual report. San José International Airport. Unpublished report.

Albion Environmental, Inc. 2009b. Annual burrowing owl breeding census at Sharpe Depot. Defense Distribution Depot San Joaquin - Sharpe Site. Unpublished report.

Albion Environmental, Inc. 2010a. Wildlife Hazard Assessment, Norman Y. Mineta San José International Airport. Unpublished report.

Albion Environmental, Inc. 2010b. Burrowing owl monitoring and management; annual report. San José International Airport. Unpublished report.

Albion Environmental, Inc. 2010c. Annual burrowing owl breeding census at 
Sharpe Depot. Defense Distribution Depot San Joaquin - Sharpe Site. Unpublished report.

Albion Environmental, Inc. 2011a. Burrowing owl monitoring and management; annual report. San José International Airport. Unpublished report.

Albion Environmental, Inc. 2011b. Annual burrowing owl breeding census at Sharpe Depot. Defense Distribution Depot San Joaquin - Sharpe Site. Unpublished report.

Albion Environmental, Inc. 2012. Annual burrowing owl breeding census at Sharpe Depot. Defense Distribution Depot San Joaquin - Sharpe Site. Unpublished report.

Barclay, J. H. 2007. Burrowing owl management at Mineta San José International Airport. Pages 146-281 in J. H. Barclay, K. W. Hunting, J. L. Lincer, J. Linthicum, and T. A. Roberts, editors. Proceedings of the California Burrowing Owl Symposium, 1112 November 2003, Sacramento, California, USA. Bird Populations Monographs No. 1. The Institute for Bird Populations and Albion Environmental, Inc., Point Reyes Station, California, USA.

Barclay, J. H. 2008a. A simple artificial burrow design for burrowing owls. Journal of Raptor Research 42:53-57.

Barclay, J. H. 2008b. A technique for nighttime trapping of burrowing owls with a bow net. Journal of Raptor Research 42:142-148.

Barclay, J. H., N. M. Korfanta, and M. J. Kauffman. 2011. Long-term population dynamics of a managed burrowing owl colony. The Journal of Wildlife Management 75:1295-1306.

Barclay, J. H. and S. Menzel. 2011. Apparent polygynous nesting by burrowing owls. Journal of Raptor Research 45:98-100.

Belthoff, J. R. and R. A. King. 2002. Nest-site characteristics of burrowing owls (Athene cunicularia) in the Snake River Birds of Prey National Conservation Area, Idaho, and application to artificial burrow installation. Western North American Naturalist 62:112-119.

Belthoff, J. R. and B. W. Smith. 2003. Patterns of artificial burrow occupancy and reuse by burrowing owls in Idaho. Wildlife Society Bulletin 31:138-144. 
Berardelli, D., M. J. Desmond, and L. Murray. 2010. Reproductive success of burrowing owls in urban and grassland habitats in southern New Mexico. The Wilson Journal of Ornithology 122:51-59.

Botelho, E. S. and P. C. Arrowood. 1998. The effect of burrow site use on the reproductive success of a partially migratory population of western burrowing owls. Journal of Raptor Research 32:233-240.

Brown, J. L. and M. W. Collopy. 2013. Immigration stabilizes a population of threatened cavity-nesting raptors despite possibility of nest box imprinting. Journal of Avian Biology 44:141-148.

Butts, K. 0. 1973. Life history and habitat requirements of burrowing owls in western Oklahoma. M. S. Thesis, Oklahoma State University, Stillwater.

Butts, K. O. and J. C. Lewis. 1982. The importance of prairie dog towns to burrowing owls in Oklahoma. Pages 46-52 in Proceedings of the Oklahoma Academy of Science.

Catlin, D. H., D. K. Rosenberg, and K. L. Haley. 2005. The effects of nesting success and mate fidelity on breeding dispersal in burrowing owls. Canadian Journal of Zoology 83:1574-1580.

Catlin, D. H. and D. K. Rosenberg. 2014. Association of sex, fledging date, and sibling relationships with post-fledging movements of burrowing owls in a non-migratory population in the Imperial Valley, California. Journal of Raptor Research 48:106117.

Collins, C. T. and R. E. Landry. 1977. Artificial nest burrows for burrowing owls. North American Bird Bander 2:151-154.

Crowe, D. E. and K. M. Longshore. 2013. Nest site characteristics and nesting success of the western burrowing owl in the eastern Mojave Desert. Journal of Arid Environments 94:113-120.

DeSante, D. F., E. D. Ruhlen, and R. Scalf. 2007. The distribution and relative abundance of burrowing owls in California during 1991-1993: Evidence for a declining population and thoughts on its conservation. Pages 1-42 in J. H. Barclay, K. W. Hunting, J. L. Lincer, J. Linthicum, and T. A. Roberts, editors. Proceedings of the California Burrowing Owl Symposium, 11-12 November 2003, Sacramento, California, USA. Bird Populations Monographs No. 1. The Institute for Bird Populations and Albion Environmental, Inc., Point Reyes Station, California, USA. 
De Smet, K. D. 1997. Burrowing owl (Speotyto cunicularia) monitoring and management activities in Manitoba, 1987-1996. Pages 123-130 in J. R. Duncan, D. H. Johnson, and T. H. Nicholls, editors. Biology and Conservation of Owls of the Western Hemisphere: Proceedings of the Second International Symposium. February 5-9, 1997, Winnipeg, Manitoba, Canada. United States Department of Agriculture Forest Service General Technical Report NC190.

Desmond M. J. and J. A. Savidge. 1999. Satellite burrow use by burrowing owl chicks and its influence on nest fate. Studies in Avian Biology 19:128-130.

Gervais, J. A., D. K. Rosenberg, and R. G. Anthony. 2003. Space use and pesticide exposure risk of male burrowing owls in an agricultural landscape. The Journal of Wildlife Management 67:155-164.

Gleason, R. S. 1978. Aspects of the breeding biology of burrowing owls in southeastern Idaho. M. S. Thesis, State University of Idaho, Moscow.

Gorman, L. R., Rosenberg, D. K., Ronan, N. A., Haley, K. L., Gervais, J. A., and V. Franke. 2003. Estimation of reproductive rates of burrowing owls. The Journal of Wildlife Management 67:493-500.

Green, G. A. 1983. Ecology of breeding burrowing owls in the Columbia Basin, Oregon. M. S. Thesis. Oregon State University, Corvallis.

Green, G. A. and R. G. Anthony. 1989. Nesting success and habitat relationships of burrowing owls in the Columbia Basin, Oregon. The Condor 91:347-354.

Green, G. A. and R. G. Anthony. 1997. Ecological considerations for management of breeding Burrowing Owls in the Columbia Basin. Pages 117-121 in J. L. Lincer and $\mathrm{K}$. Steenhof, editors. The Burrowing Owl, its biology and management: including the Proceedings of the First International Symposium, 13-14 November 1992, Bellevue, Washington, USA. Raptor Research Report Number 9. Allen Press, Lawrence, Kansas, USA.

Green, G. A., R. E. Fitzner, R. G. Anthony, and L. E. Rogers. 1993. Comparative diets of burrowing owls in Oregon and Washington. Northwest Science 67:88-93.

Greenwood, P. J. and P. H. Harvey. 1982. The natal and breeding dispersal of birds. Annual Review of Ecology and Systematics 13:1-21.

Haug, E. A. 1985. Observations on the breeding ecology of burrowing owls in Saskatchewan. Doctoral dissertation. University of Saskatchewan, Saskatoon. 
Haug, E. A. and L. W. Oliphant 1990. Movements, activity patterns, and habitat use of burrowing owls in Saskatchewan. The Journal of Wildlife Management 54:27-35.

Haug, E. A., B. A. Millsap, and M. S. Martell. 1993. Burrowing Owl (Speotyto cunicularia). In A. Poole and F. Gill, editors, The Birds or North America. No 61. Academy of Natural Sciences, Philadelphia, PA; American Ornithologists' Union, Washington, DC.

Henny, C. J. and L. J. Blus. 1981. Artificial burrows provide new insight into burrowing owl nesting biology. Raptor Research 15:82-85.

Holmes, A. L., G. A. Green, R. L. Morgan, and K. B. Livezey. 2003. Burrowing owl nest success and burrow longevity in north central Oregon. Western North American Naturalist 63:244-250.

Houston, C. S., D. G. Hjertaas, R. L. Scott, and P. C. James. 1996. Experience with burrowing owl nest-boxes in Saskatchewan with comment on decreasing range. Blue Jay 54:136-140.

James, P. C. and R. H. M. Espie. 1997. Current status of the burrowing owl in North America: an agency survey. Pages 3-5 in J. L. Lincer and K. Steenhof, editors. The Burrowing Owl, its biology and management: including the Proceedings of the First International Symposium, 13-14 November 1992, Bellevue, Washington, USA. Raptor Research Report Number 9. Allen Press, Lawrence, Kansas, USA.

James, P. C. and T. J. Ethier. 1989. Trends in the winter distribution and abundance of burrowing owls in North America. American Birds 43:1224-1225.

Johnson, B. S. 1997. Reproductive success, relatedness, and mating patterns of colonial Burrowing Owls. Pages 64-67 in J. L. Lincer and K. Steenhof, editors. The Burrowing Owl, its biology and management: including the Proceedings of the First International Symposium, 13-14 November 1992, Bellevue, Washington, USA. Raptor Research Report Number 9. Allen Press, Lawrence, Kansas, USA.

Johnson, D. H., D. C. Gillis, M. A. Gregg, J. L. Rebholz, J. L. Lincer, and J. R. Belthoff. 2013. Users guide to the installation of artificial burrows for burrowing owls. Version 2.0. Tree Top Inc., Selah, Washington.

Keppers, J. L., M. K. Skoruppa, M. C., Woodin, and G. C. Hickman. 2008. Use of artificial burrows by western burrowing owls and other vertebrates during winter in southern Texas. Bulletin of the Texas Ornithological Society 41:59-64. 
King R. A. and J. R. Belthoff. 2001. Post-fledging dispersal of burrowing owls in southwestern Idaho: characterization of movements and use of satellite burrows. The Condor 103:118-126.

Klute, D. S., L. W. Ayers, M. T. Green, W. H. Howe, S. L. Jones, J. A. Shaffer, S. R. Sheffield, and T. S. Zimmerman. 2003. Status assessment and conservation plan for the western burrowing owl in the United States. United States Department of Interior, Fish and Wildlife Service, Biological Technical Publication FWS/BTPR6001-2003, Washington, D. C.

Korpimaki, E., M. Lagerstrom, and P. Saurola. 1987. Field evidence for nomadism in Tengmalm's owl Aegolius funereus. Ornis Scandinavica 18:1-4.

Lantz, S. J., C. J. Conway, and S. H. Anderson. 2007. Multiscale habitat selection by burrowing owls in black-tailed prairie dog colonies. The Journal of Wildlife Management 71:2664-2672.

Leopold, A. 1966. A Sand County Almanac: With other essays on conservation from Round River. Oxford University Press, New York.

Liberg, O. and T. von Schantz. 1985. Sex-biased philopatry and dispersal in birds and mammals: the Oedipus hypothesis. The American Naturalist 126:129-135.

Lutz, R. S. and D. L. Plumpton. 1999. Philopatry and nest site reuse by burrowing owls: implications for productivity. Journal of Raptor Research 33:149-153.

MacCracken, J. G., D. W. Uresk, and R. M. Hansen. 1985. Vegetation and soils of burrowing owl nest sites in Conata Basin, South Dakota. The Condor 87:152-154.

Martin, D. J. 1973. Selected aspects of burrowing owl ecology and behavior. The Condor 75:446-456.

Millsap, B. A. and C. Bear. 1988. Cape Coral burrowing owl population monitoring. Annual Performance Report, Nongame Wildlife Section, Florida Game and Fresh Water Fish Commission, Tallahassee, Florida, USA.

Millsap, B. A. and C. Bear. 1990. Double-brooding by Florida burrowing owls. The Wilson Bulletin 102:313-317.

Millsap, B. A. and C. Bear. 1997. Territory fidelity, mate fidelity, and dispersal in an urban-nesting population of Florida Burrowing Owls. Pages 91-98 in J. L. Lincer and $\mathrm{K}$. Steenhof, editors. The Burrowing Owl, its biology and management: including the Proceedings of the First International Symposium, 13-14 November 1992, Bellevue, 
Washington, USA. Raptor Research Report Number 9. Allen Press, Lawrence, Kansas, USA.

Newton, I. 2008. The migration ecology of birds. Academic Press, Elsevier, London, United Kingdom.

Pärt, T. 1995. The importance of local familiarity and search costs for age-and sexbiased philopatry in the collared flycatcher. Animal Behaviour 49:1029-1038.

Plumpton, D. L. 1992. Aspects of nest site selection and habitat use by burrowing owls at the Rocky Mountain Arsenal, Colorado. Doctoral dissertation, Texas Tech University, Lubbock.

Plumpton, D. L. and R. S. Lutz. 1993. Nesting habitat use by burrowing owls in Colorado. Journal of Raptor Research 27:175-179.

Poulin, R. G., L. D. Todd, K. M. Dohms, R. M. Brigham, and T. I. Wellicome. 2005. Factors associated with nest-and roost-burrow selection by burrowing owls (Athene cunicularia) on the Canadian prairies. Canadian Journal of Zoology 83:1373-1380.

Poulin, R. G., L. D. Todd, T. I. Wellicome, and R. M. Brigham. 2006. Assessing the feasibility of release techniques for captive-bred burrowing owls. Journal of Raptor Research 40:142-150.

Remsen J. V. 1978. Bird species of special concern in California, an annotated list of declining or vulnerable species. California Department of Fish and Game, Nongame Willife Investigation Project PR W-54-r-9, Report No. 78-1.

Rich, T. 1984. Monitoring burrowing owl populations: Implications of burrow reuse. Wildlife Society Bulletin 12:178-180.

Riding, C. S. 2010. Effects of old nest material on occupancy and reuse of artificial burrows, and breeding dispersal by burrowing owls (Athene cunicularia) in sourthwestern Idaho. M. S. Thesis, Boise State University, Idaho.

Ronan, N. A. 2002. Habitat selection, reproductive success, and site fidelity of burrowing owls in a grassland ecosystem. M. S. Thesis, Oregon State University, Corvallis.

Ronan, N. A. and D. K. Rosenberg. 2014. Response of burrowing owls to experimental removal of satellite burrows. The Journal of Wildlife Management 78:1115-1119. 
Rosenberg, D. K. and K. L. Haley. 2004. The ecology of burrowing owls in the agroecosystem of the Imperial Valley, California. Studies in Avian Biology 27:120135.

Ross, P. V. 1974. Ecology and behavior of a dense colony of burrowing owls in the Texas Panhandle. M. S. Thesis. West Texas State University, Canyon.

Sanz-Aguilar, A., A. Béchet, C. Germain, A. R. Johnson and R. Pradel. 2012. To leave or not to leave: survival trade-offs between different migratory strategies in the greater flamingo. Journal of Animal Ecology 81:1171-1182.

Sawyer J. O. and T. Keeler-Wolf . 1995. A manual of California vegetation. California Native Plant Society, Sacramento, California, USA.

Sheffield, S. R. 1997. Current status, distribution, and conservation of the burrowing owl (Speotyto cunicularia) in midwestern and western North America. United States Department of Agriculture Forest Service General Technical Report NC, 399-408.

Shuford, W. D. and T. Gardali, editors. 2008. California Bird Species of Special Concern: A ranked assessment of species, subspecies, and distinct populations of birds of immediate conservation concern in California. Studies of Western Birds 1. Western Field Ornithologists, Camarillo, California, and California Department of Fish and Game, Sacramento.

Smith, B. W. and J. R. Belthoff. 2001a. Burrowing owls and development: short distance nest burrow relocation to minimize construction impacts. Journal of Raptor Research 35:385-391.

Smith, B. W. and J. R. Belthoff. 2001b. Effects of nest dimensions on use of artificial burrow systems by burrowing owls. Journal of Wildlife Management 65:318-326.

Smith, B. W. and J. R. Belthoff. 2001c. Identification of ectoparasites on burrowing owls in southwestern Idaho. Journal of Raptor Research 35:159-161.

Smith, M. D., C. J. Conway and L. A. Ellis. 2005. Burrowing owl nesting productivity: a comparison between artificial and natural burrows on and off golf courses. Wildlife Society Bulletin 33:454-462.

Thomsen, L. 1971. Behavior and ecology of burrowing owls on the Oakland Municipal Airport. The Condor 73:177-192. 
Trulio, L. A. 1995. Passive relocation: A method to preserve burrowing owls on disturbed sites . Journal of Field Ornithology 66:99-106.

Trulio, L. A. 1997. Strategies for protecting Western Burrowing Owls (Speotyto cunicularia hypugaea) from human activities. Pages 461-465 in J. R. Duncan, D. H. Johnson, and T. H. Nicholls, editors. Biology and Conservation of Owls of the Western Hemisphere: Proceedings of the Second International Symposium. February 5-9, 1997, Winnipeg, Manitoba, Canada. United States Department of Agriculture Forest Service General Technical Report NC190.

United States Department of Agriculture [USDA]. 2014. Natural Resources Conservation Service. Web Soil Survey. <http://websoilsurvey.sc.egov.usda.gov/ App/WebSoilSurvey.aspx> Accessed 18 August 2014.

Wellicome, T. I. and E. A. Haug. 1995. Second Update of Status Report on the Burrowing Owl, Speotyto cunicularia, in Canada. Committee on the Status of Endangered Wildlife in Canada, Canadian Wildlife Sevice, Environment Canada, Ottawa, Ontario.

Wellicome, T. I., G. L. Holroyd, K. Scalise, and E. R. Wiltse. 1997. The effects of predator exclusion and food supplementation on burrowing owl (Speotyto cunicularia) population change in Saskatchewan. Pages 487-497 in J. R. Duncan, D. H. Johnson, and T. H. Nicholls, editors. Biology and Conservation of Owls of the Western Hemisphere: Proceedings of the Second International Symposium. February 5-9, 1997, Winnipeg, Manitoba, Canada. United States Department of Agriculture Forest Service General Technical Report NC190.

Wesemann, T. and M. Rowe. Factors influencing the distribution and abundance of burrowing owls in Cape Coral, Florida. 1987. Pages 129-137 in L. W. Adams and D. L. Leedy, editors. Integrating Man and Nature in the Metropolitan Environment. Proceedings of the National Symposium of Urban Wildlife. National Institute for Urban Wildlife, Columbia, Maryland, USA.

Western Regional Climate Center [WRCC]. 2014. Climate Summaries. Manteca, California. <http://www.wrcc.dri.edu/cgi-bin/cliMAIN.pl?ca5303> Accessed 18 August 2014.

Western Regional Climate Center [WRCC]. 2014. Climate Summaries. San Jose, California. <http://www.wrcc.dri.edu/cgi-bin/cliMAIN.pl?casjos+nca> Accessed 18 August 2014. 
Zarn, M. 1974. Burrowing owl (Speotyto cunicularia hypugaea). Habitat management series for unique or endagered species. Report Number 11, T/N-250 Bureau of Land Management, Denver, Colorado, USA. 


\section{APPENDICES}


Appendix 1: Burrowing owl monitoring map for San José International Airport.

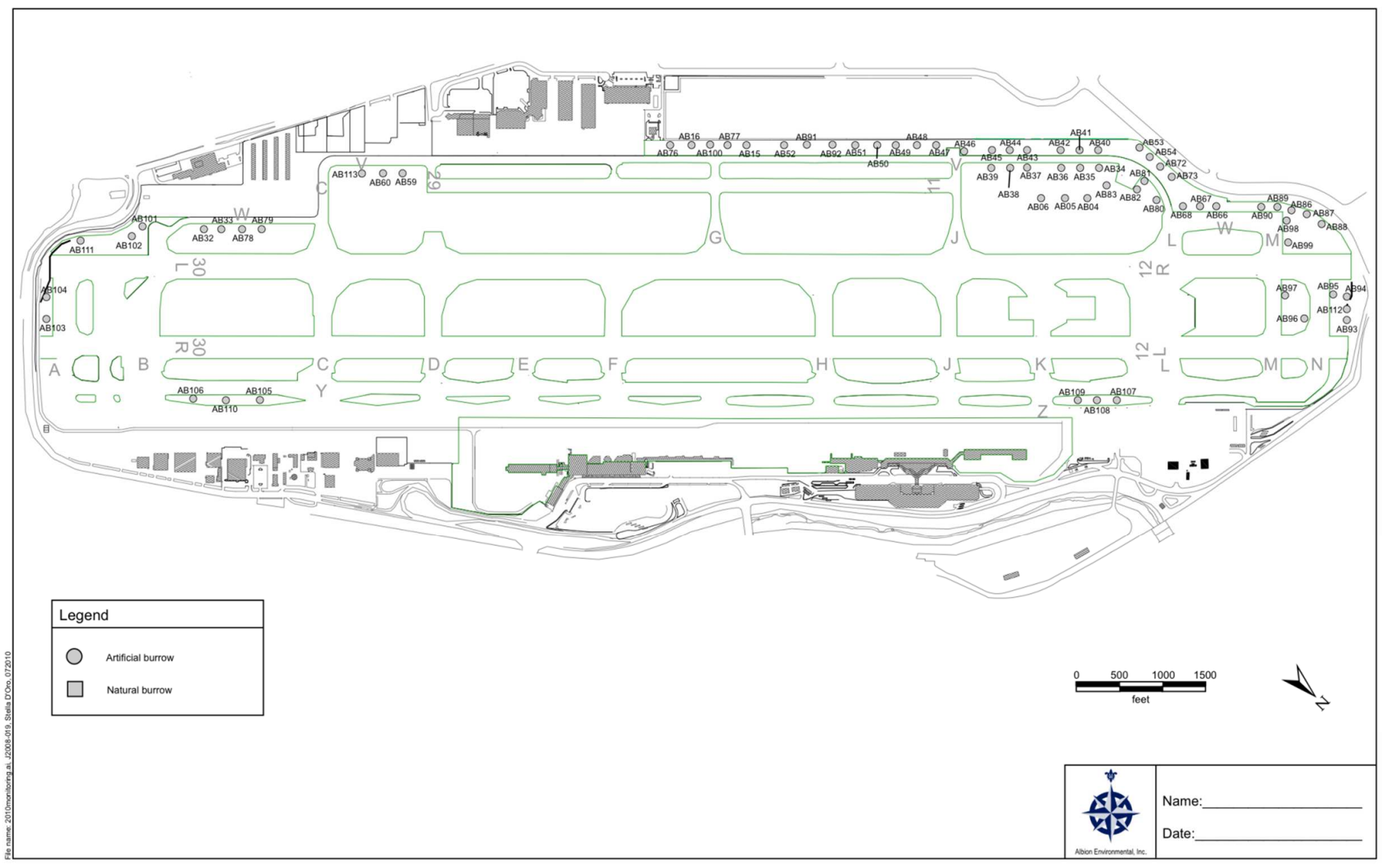


Appendix 2: Burrowing owl data collection sheet for San José International Airport.




Appendix 3: Burrowing owl survey map for Sharpe Depot.

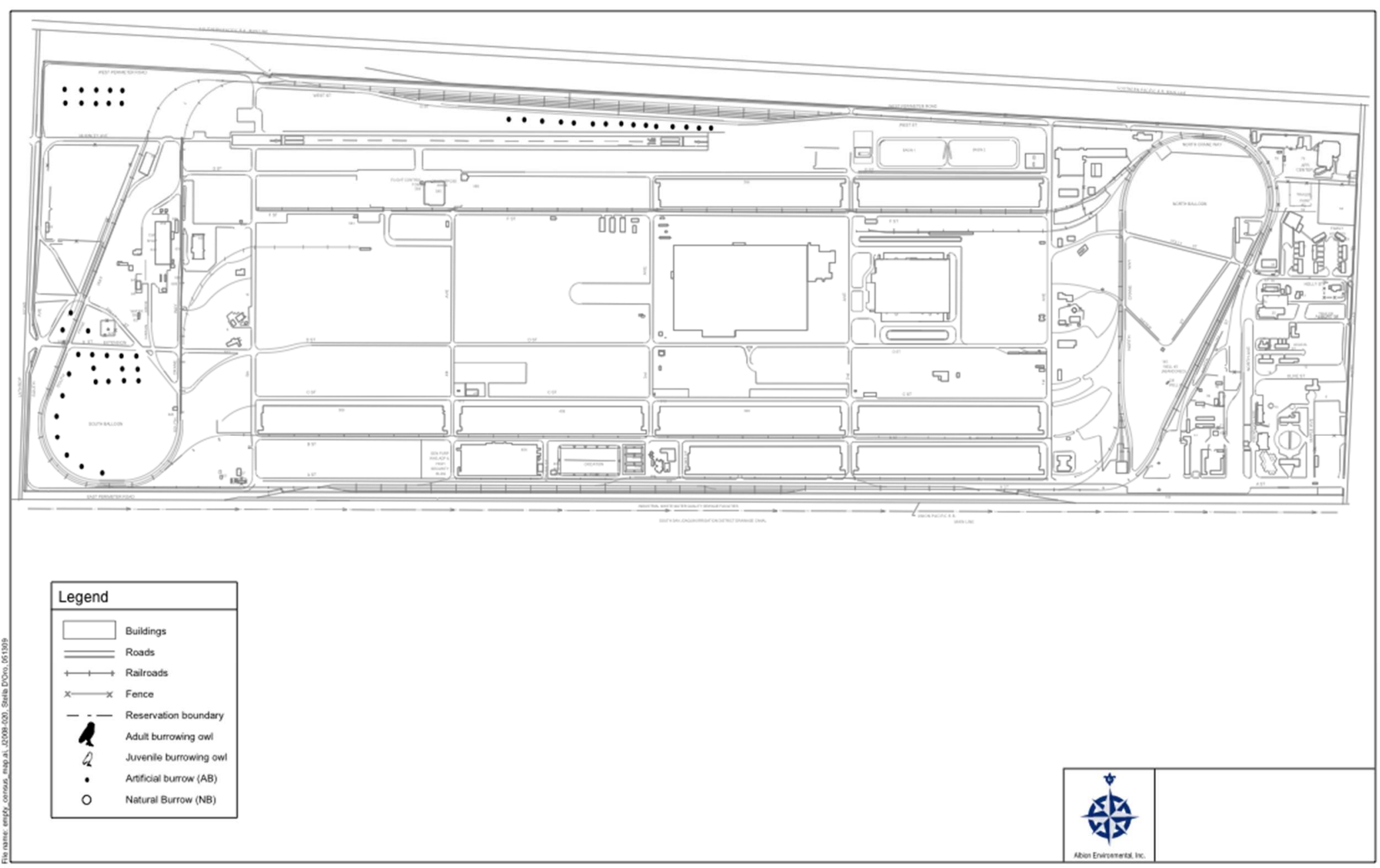




\section{San Jose State University Institutional Animal Care and Use Committee}

\section{(2) LETTER OF OFFICIAL PROTOCOL REVIEW}

Date: November 27, 2012

Dear Lynne,

The animal care and use portion of your research proposal indicated below was reviewed by the Institutional Animal Care and Use Committee (IACUC). The status of your proposal is as follows:

Principal Investigator(s): Dr Lynne Trulio

Co-Investigator(s): Sandra Menzel

Protocol \#: 2012-H

Title: Effects of Artificial Burrows on Burrowing Owl Demography.

The application was approved without modification by the IACUC.

Approval date: $\underline{\text { January 1,2013 }}$ * Expiration Date: December 31, 2015

The IACUC must be informed in writing of any proposed changes to the approved protocol outline and approval must be granted in writing by the IACUC before any change is instituted. If you wish to continue the approved outline beyond the expiration date, it is required that you resubmit an animal care and use application for IACUC approval in November 2015.

Protocol number 2012-H may only be used by the Principal Investigator and participants included on the approved application form. The protocol number will be required on grant or contract proposals to fund the project. To maintain valid protocol approval, route a copy of all renewed permits, requests for permit extensions, correspondence with the P.I. and government agencies and related business to the UAC office at extended zip 0100 to be included in your animal use file if applicable. If you have any questions, feel free to contact me at 408-924-4929.

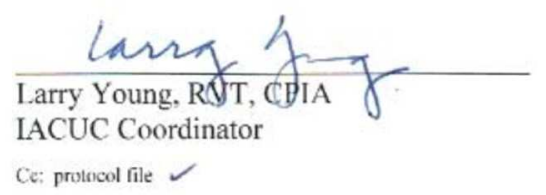

This protocol has been approved as a Health Risk Category One level project (RC-1).

Please refer to the attached risk eategory description page for relevant personnel safety information pertaining to this study. 